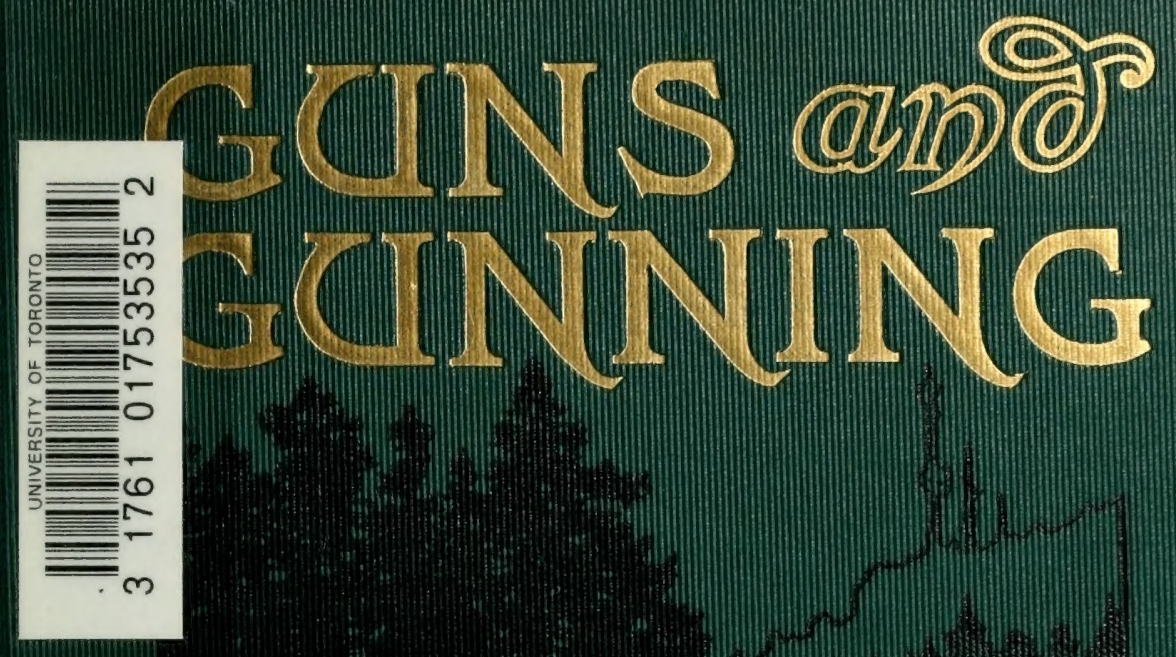




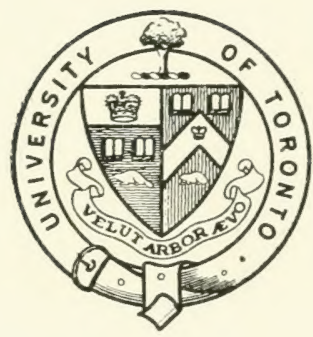

唒resented to

The Tithrary of the

Alnurersity of Tlarento

by

The Estate of the late Hon. W.H. McGuire 


Guns and Gunning 



\title{
Guns and Gunning
}

By Bellmore H. BRowne

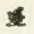 \\ Edited by DAN BEARD
}

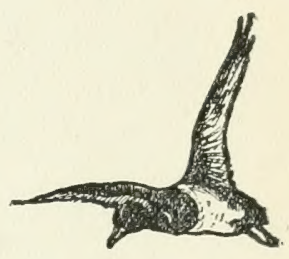

Written for and Published by

J. STEVENS ARMS \& TOOL CO.

Chicopee Falls, Mass.

U.S. A. 

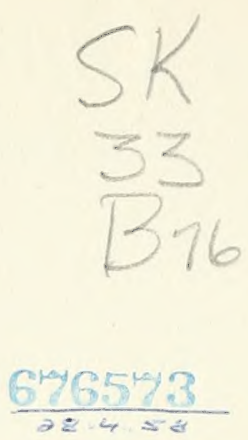

Copyrighted 1908

J. STEVENS ARMS \& TOOL CO.

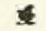

April

Press of Loring-Axtell Company

Springfield, Mass. 


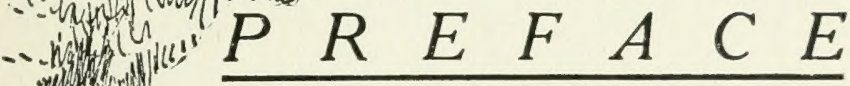

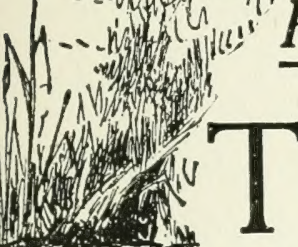
desk, and it stifles the sickening odors from the reeking streets.

"Tis the silence of the Forest Crowding in upon our doors,"

and as the associations born of its perfume fill our brain to the exclusion of everything else, what care we for musty papers, stocks and bonds, bank books and checks, bills and duns, or the tiresome ring of the telephone bell, the monotonous ticking of the telegraphic instruments, the stupid contents of ledgers, the columns of interminable-figures, the wording of perfunctory letters, or any of the wheels which compose the senseless artificialities of modern life?

Above the hum of the multitude, the roar of the elevated trains, the harsh clang of trolley car bells, the vile oaths of truckmen, and the insane medley of city noises, there comes to us sweet and clear, the voice of dear old Mother Nature, bidding 
us home, calling us to the wilderness, our old, old home, the original homestead of the human race, antedating the pyramids and designed and constructed for us by the Divine Architect himself !

It is the soul-stirring call of man primeval now ringing in our ears, and it causes us to become restive, to stretch our necks like captive wild geese when they see the flying wedge of their free brothers clearing the misty morning air, and hear the honk of the wise old leading gander as he bids them come!

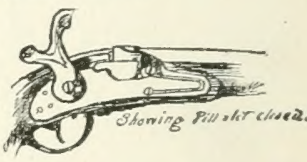

This book is an answer to "the call of the wild," and it is our sincere wish that the very practical hints and advice here given may be of service to the novice and not altogether unwelcome to the veteran.

Our own experience teaches us that no matter how often we visit the woods we always find something new to learn and no one man knows it all.

Especially do we wish this book to be of service to the youth of this country, to those healthy, wholesome American lads whose normal minds give them a natural desire to spend their vacation in the open with their trusty Stevens on their shoulders.

For their benefit we suggest that they organize STEVENS RIFLE CLUBS 
to practice shooting at targets and thus fit themselves for their vacation trips in the woods, and also to develop that manly self control and calm resourcefulness which were the marked characteristics of their forbears, and which have done so much to make the American people great and their country one that is respected by every nation in the world.

Let each group of boys organize a club, select a president, treasurer, secretary and a corresponding secretary, the latter to attend to the correspondence with other Stevens Rifle clubs.

The J. Stevens Arms \& Tool Company will gladly do all in its power to encourage and help the organizations in their work of perfecting themselves in the proper care and use of firearms.

When Mr. 1. H. Page of the J. Stevens Arms \& Tool Company suggested to the editor that he should get up this book, the latter had so much work on hand that he was in despair until he secured the talented young artist and arctic explorer, Mr. Bellmore $\mathrm{H}$. Browne to help him in the task, or rather the work of love, and he could not have found a more agreeable gentleman, a more accomplished real wilderness hunter, or a more practical outdoor man for the work. The reader is indebted to Mr. Browne for the 
whole of this book - the editor's part consisted only in supervising the practical bookmaking part and editing the manuscript during the absence of the author on an exploring expedition to the far icebound Mt. McKinley, from which at the present writing he is not expected to return until after this book is published and in the readers' hands.

EDITOR.

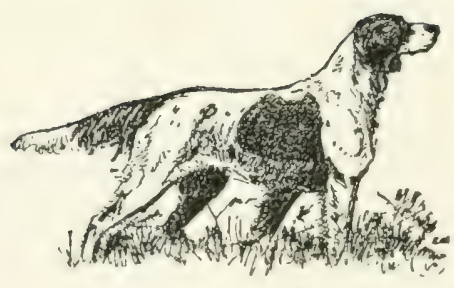




\section{$\begin{array}{llllllll}C & O & N & T & E & N & T & S\end{array}$ \\ 4}

CHAPTER I

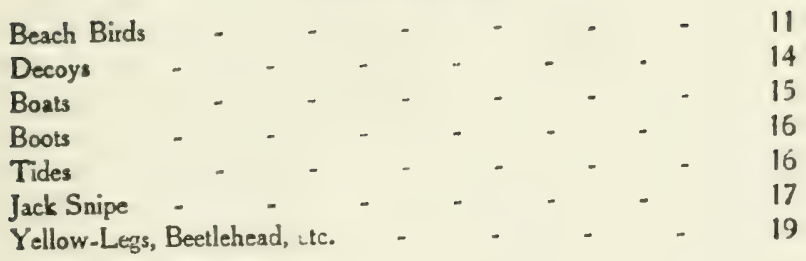

CHAPTER II

Hunting with the Rille

\section{CHAPTER III}

The Shotgun

CHAPTER IV

Wild Fowl - $\quad$ - $\quad$ - $\quad$ - $\quad$ - 41

Blinds _ - $\quad$ - $\quad$ - $\quad$ - $\quad$ - 44

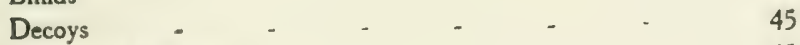

Number of Decoys _ _ _ _ _ _ $\quad$ - 45

Mixed Shooting _

Fitting out a Stool _ _ _ _ _ _ 47

Boats - $\quad$ - $\quad$ - $\quad$ - $\quad$ - 48

Clothes - $\quad$ - $\quad$ - $\quad$ - $\quad$ - $\quad$ - 49

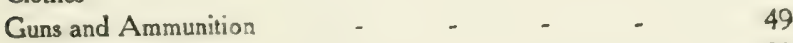

Ammunition - $\quad$ - $\quad$ - $\quad$ - $\quad$ - $\quad$ - 50

Size of Shot $\quad-\quad \ldots \quad \ldots \quad \ldots \quad \ldots$

Hunting - $\quad$ - $\quad$ - $\quad$ - $\quad$ - $\quad$ - 52

Shooting over Decoys $\quad$ - $\quad \ldots \quad$ - $\quad$ _ 52

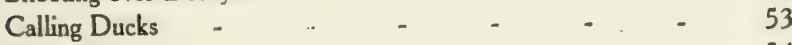

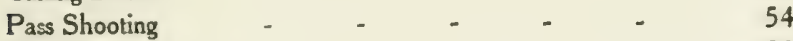

"Jumping" Ducks - _ _ _ _ _ _ 55

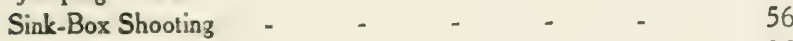

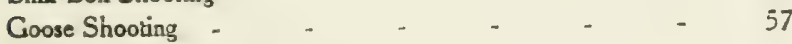




\section{CHAPTER V}

Upland Shooting

Grouse and Woodcock _ _ _ _ _ _ _ 60

Quail

"Prairie Chickens"

CHAPTER VI

A Brief History of Firearms - _ _ _ $\quad$ - $\quad 69$

Marksmanship

CHAPTER VII

The Wilderness

Wrod and Water

Neatness and Order

Tents

Flies

Fires

Stoves

Baking Fires

Frying Fires

Roasting Fires

Boiling

Cooking Utensils

Camp Cooking

Grub

Beds

Packing

Packing Horses

Packing Dogs

Man Packing

Fording Streams

Pack Fording

Pole Fording

Woodcraft

Hunting

Still Hunling 



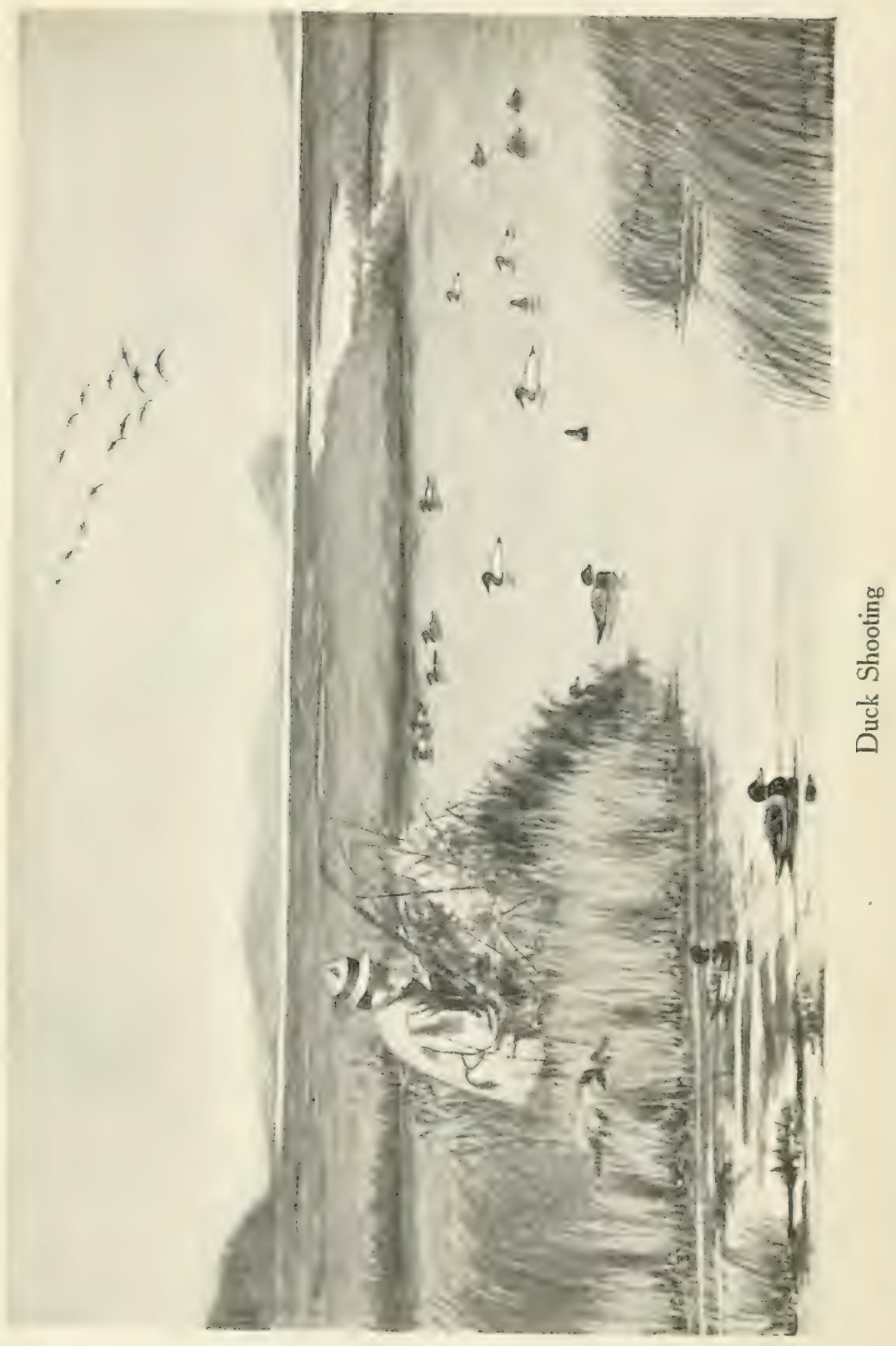




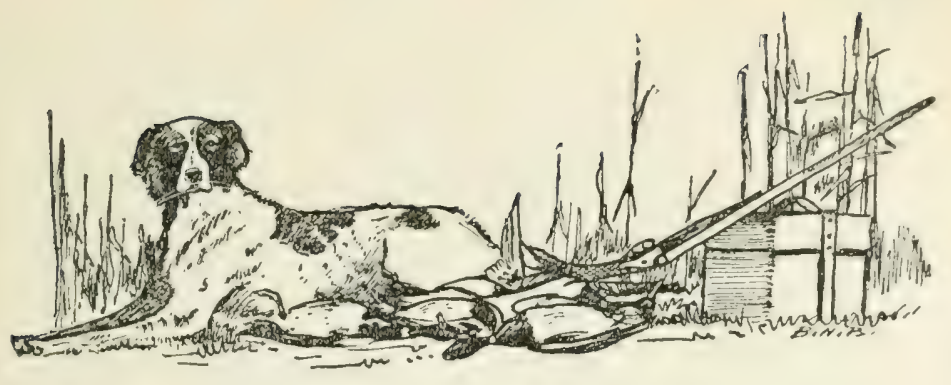

CHAPTER I

\section{女 \\ Beach Birds}

T THEN the beaches begin to warm under the Spring sun, and the fresh green of the new grass changes the salt marshes, the beach birds sweep northward along our coasts. There are over 60 species of shore birds found in North America, and among them are some of our most highly prized game birds. The flights that some of these delicate looking birds make are remarkable. Some of them make the round trip from South America to the Arctic in the course of a year. The snipe arrives in our Northern States between the middle of April and the early part of May, on their way to the North, where they breed; and return in the latter part of August, or the beginning of September, making only a short stay. All the birds of this genus seem to go North to breed, and to return 
Southward as soon as the young are able to fly. Single birds are to be met with in summer or at almost any season, but they are male birds that for some reason have not mated, and have remained in the warm Southland.

The flight of the snipe genus is easy and rapid, and their movements on land are dignified and graceful. If necessary they are good swimmers, and some species are proficient at diving. Their chief resorts are the salt marshes along the seacoasts, and at low tide they are fond of wading on the mud-flats in pursuit of their food. They live on larvæ and insects. They are, as a family, of a very sociable disposition; and this fact, added to their habit of flying in compact flocks, is the chief reason for their rapid decrease in numbers. A flock of snipe after being shot at, sometimes return and give the gunner another chance, and particularly so if some of them have been wounded by the hunter, and utter their plaintive whistle.

The smaller varieties often congregate in immense flocks, and as many as twenty or more birds have been killed with a single barrel, by pot hunters. One of the chief pleasures of beach-bird shooting is the endless varieties of snipe that come to the hunter's stool. Each of the species has a distinctive whistle or call, and the experienced snipe hunter not only knows the call of each variety, but can imitate it with remarkable skill. 
When hunted continually, however, the beach birds become very wary, and it takes a master to whistle in an old "Beetlehead" or "tattler." The snipe is easily killed, and heavy shot is not needed. No. 9 shot, and even 10s are usually used.

At low tide the birds are hard to approach, as they congregate on the great expanses of soft mud along our coasts. As the tide rises they fly inland to the large salt marshes. The hunter usually stations himself in a good blind near a shallow pond, and as the birds are driven inland by the encroaching water, they offer many good shots to the hidden gunner.

As beach-bird shooting is at its best in the late summer, the climatic conditions are far pleasanter than in duck shooting; besides the mosquitoes and hot sun there is nothing to worry the hunter. The salt marshes are thirst-inducing, and the experienced bayman always stocks his blind with a jug of cool water.

There is something restful about shore-bird shooting. Nothing is more soothing than the sound of the summer wind rustling through the marsh grass, and of the surf pounding on some hard sea beach in the distance. Far at sea cat-boats are circling about a bluefish school, and the hunter becomes lost in watching the white sails until a yellow-leg's whistle from the blue sky reminds him of his errand. The most difficult thing to learn in bay-

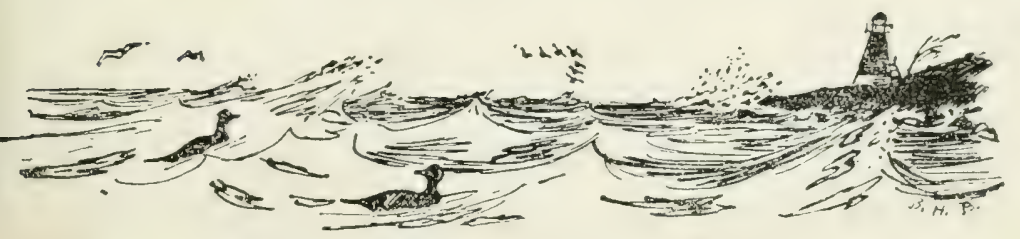


bird shooting is the whistling or calling. Experience is the only teacher, and besides, a man must be especially gifted to acquire the art. Men who are born and bred near the snipe marshes become adepts at calling, and there is no feat in bird shooting more difficult than whistling a wary, black-bellied plover down from the blue sky.

\section{4 \\ DECOYS}

All the beach bird clan decoy readily. Clam shells, or lumps of mud on sticks will answer sometimes for a stool in out-of-the-way localities. The best decoys, however, are none too good, and a these can be bought in any reliable sporting store. Decoys of tin can be used, that are folding, and pack snugly in a small box. They are very handy, and serve their purpose well. In snipe shooting the stool should be placed up wind from, and not too close to the blind.

It is a good plan for the hunter to supply himself with a number of thin sticks before the hunt, as the dead birds can be used as decoys by inserting one end of the stick under the head, and pushing the other end into the mud. This is not really necessary, however, unless the stool is small. About 20 decoys make a good stool ; the number depending largely on the trouble the hunter wishes to take.

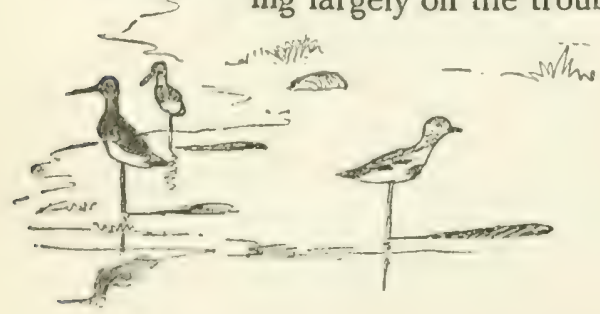


It is a thrilling sight to see a large flock of yellow-legs, or black-bellied plovers, decoying; and the exchanging of whistles between the flying birds and the hunter adds greatly to the sport. Flocks of small sandpipers will often alight among the decoys, and will prove a great help in decoying larger birds, if unmolested by the sportsman.

The smaller species seem to realize the intelligence and watchfulness of the big snipe, and rely on them for warning in case of danger. The yellow-leg has been given the name of "tattler" on account of its habit of warning other birds on the approach of a hunter.

\section{3

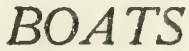

The flat bottom skiff is the best boat to use in snipe shooting.

The hunter often finds it necessary to follow winding sloughs for long distances. Sometimes they are very shallow, or "peeter out" altogether; and then he must drag his boat across the mud until another channel is found.

Mud is the most unpleasant feature of beach bird hunting. It gets on the clothes, and gun; and if the hunter is unlucky enough to slip and fall, it is doubiful if his best friend would recognize him. A good pole is often useful, as rowing is tedious in very shallow water. The boat should be light 
enough for one man to drag, if necessary, and a long painter will be helpful in tying the boat at low tide.

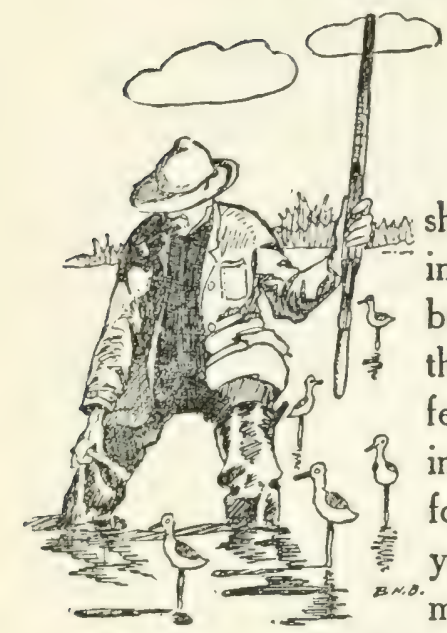

\section{BOOTS}

Good hip boots are a comfort in snipe shooting. So much wading and mud-walking must be done, that ordinary shoes would be useless. The boots should fit tightly, or the clinging mud will pull them from your feet. It is an exasperating thing to get stuck in the mud. The harder you pull on one foot to get it free, the more firmly planted your other foot gets; at last, covered with mud and perspiration, you gain the bank, and make a solemn vow that the snipe marshes will never see you again. As a flock of snipe usually choose this inopportune time for decoying, you must be an enthusiast indeed to remain calm. But it is the clothes we wear that make us clumsy. A man can go through the stickiest mud without much trouble if his legs are bare. When the hunter is caught in quicksand, or a mud hole, he should pull his feet out of his boots; then he can move more easily.

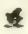 \\ TIDES}

A good knowledge of the tides is of great importance to the snipe hunter. It not only enables 
him to navigate the net-work of sloughs with more or less comfort, but it also helps him in hunting. A stranger on some of our large snipe marshes would be practically helpless unless he was accompanied by some one who knew the flats and tides.

The sportsman should be careful in tying his boat, as it is a common thing in water-fowl shooting to have it drift away and leave the hunter marooned on some marshy island.

The writer remembers making a long swim in November, after an escaped boat; if you ever experience this kind of adventure, you will tie your boat securely ever after.

In all large bays and winding water-courses, where the tides are strong, there are always eddies, or reaches, where the tide is either favorable or sluggish. Then again, a knowledge of the tides will help the hunter, and save him many a long and weary pull against the swift current.

\section{进 \\ JACK SNIPE}

At the head of the snipe family, or scolopacidae, we have the American woodcock, and the Wilson's snipe. As the woodcock is an upland bird in all but family, we will pass him by here, and speak of the Wilson's snipe.

\section{7}

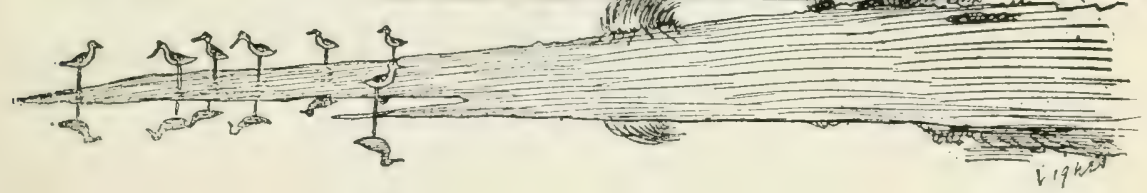


In his class there is no gamer bird than the Wilson, or, as hunters call him, the "jack" snipe.

As he is rarely found in thick brush we will not compare him with the woodcock; and no other bird in the snipe family can rival him.

The most successful way of hunting "jacks" is with a good, steady dog. The jack "lies" well, and has a strong, erratic flight, that makes him a difficult mark to inexperienced gunners. After flying 20 or 30 yards the jack settles down and flies more evenly; and the veteran snipe hunter waits if possible for this change, before discharging his gun. When flushed, it utters at intervals a loud "scaip! scaip!" Its flight is short unless badly frightened, and it can be marked down and followed by the hunter. The habits and haunts of the jack snipe are so easily affected by climatic and other conditions, that an intimate knowledge of its peculiarities is necessary to find and approach it.

On windy days the jack is very wild; its senses are so keen that it is most difficult for the hunter to approach within gun shot. Leave your dog at home in bad weather, and hunt down wind. In this way you can get some good shots; as the jack will rise against the wind, or toward the hunter.

On warm, sunny days, they lie close, and a good setter or spaniel is necessary to find and flush them.

As a table bird, the jack snipe has no superior. 
They begin their northward migration in March, and by July are scattered throughout the Middle States, and the far north, for breeding. In their migrations they are found from South America to the Arctic Circle; and many winter in our Southern States.

They are to be found in low, marshy ground. A flooded cow-pasture is a favorite spot, but they haunt both fresh and salt water marshes.

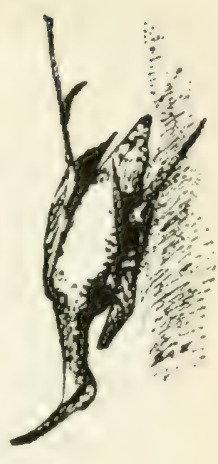

\section{F}

\section{YELLOW-LEGS, BEETLEHEAD Etc.}

As the difference between the snipe and plover family is largely physical, and makes little difference to the sportsman, I will speak of them as one. The principal birds that go to make up a shore-bird hunter's bag, are the yellow-leg, beetlehead or blackbellied plover, willet, dowitcher, robin snipe, and the curlews.

The curlew is rare on the Eastern Coast of America, but it is still quite plentiful in Central, and Western North America. There are several species of curlew; but they can be easily recognized by their large size and distinctive whistle.

Their whistle is easily imitated, and they decoy readily. In fact, curlew often become confused when shot at, and return again to the hunter. They sometimes congregate in immense flocks during their 
migrations, and "string out" in the manner of wild geese.

Beach birds, after frequenting a marsh, usually fly in compact flocks, while the travelling birds, or "strangers," are apt to string out in the manner of ducks. The black-bellied plover, or beetle-head resemble the golden plover. They are found along our seacoasts and large inland waters.

The upland plover, as the name implies, is found as a rule on inland hills and prairies. The best upland plover shooting in America today is enjoyed in Texas, during the winter months. Both the beetle-headed and golden plover are highly prized as food and game birds. At times the beetle-head is extremely shy and watchful; whistling in a flock of these birds is always a difficult feat.

They are found at times in the company of other beach birds, such as yellow-legs, willet, etc. They differ from the rest of the plover family in having a small hind toe.

The yellow-leg snipe is found in North America wherever there is water. This large and graceful beach bird deccys readily, and is highly prized by epicures.

They are found at times in large flocks, and mingle freely with other aquatic birds.

The writer once saw a solitary yellow-leg vainly trying to keep up with a flock of greenwinged teal; but his efforts were unavailing, and he soon gave up the race 
The principal draw-back to beach-bird shooting is, that there are comparatively few places where the birds are numerous enough to make it worth while.

On the Pacific coast especially, almost all of the snipe killed are shot by duck hunters. In the Autumn they alight in large flocks on the "flats" bordering the northwestern duck marshes. If the hunter who sees them is not having much success with ducks, he often attempts a stalk on the snipe, or plover, and "rakes" them while they are "bunched up." The Atlantic coast is far better suited for beach-bird shooting than the Pacific; due to the greater number of sandy beaches and shallow bays.

The south side of Long Island is justly famous for its bay-bird shooting and under favorable conditions the sportsman can still get a fair bag.

Beach birds are growing fewer every year, and good laws, strongly enforced, are necessary to keep them from being exterminated. Compared to our upland birds, they are easily killed. Their sociable nature makes them an easy prey to the market hunter.

The only way to save them is to absolutely prohibit their sale and protect them during the Spring migration. Due to the rapid growth of our country, and the speed with which the wilderness is being settled, our game laws are inadequate. Even the breeding-grounds of our water-fowl are in danger unless laws are passed and enforced to protect 
them. In Northwestern Alaska certain breedinggrounds of water-fowl are regularly "picked" at short intervals. This wholesale destruction of eggs does untold damage. As matters stand now, the less shooting there is, the better chances we will have for a bountiful supply of birds in the future. Every sportsman should limit his bag, and get his enjoyment from the open air and the beauties of nature, rather than from the slaughter of these beautiful and useful birds.

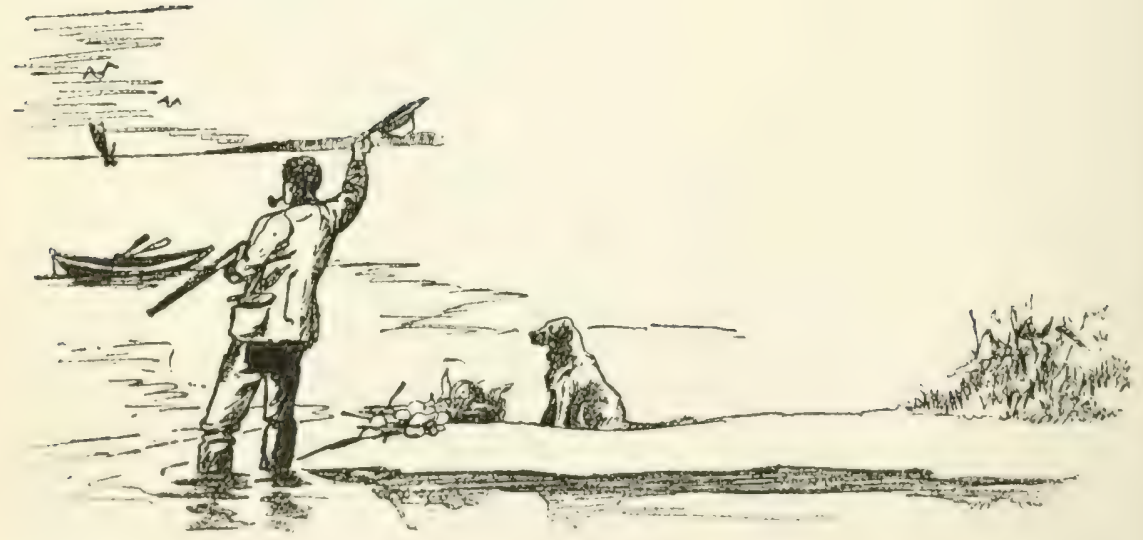





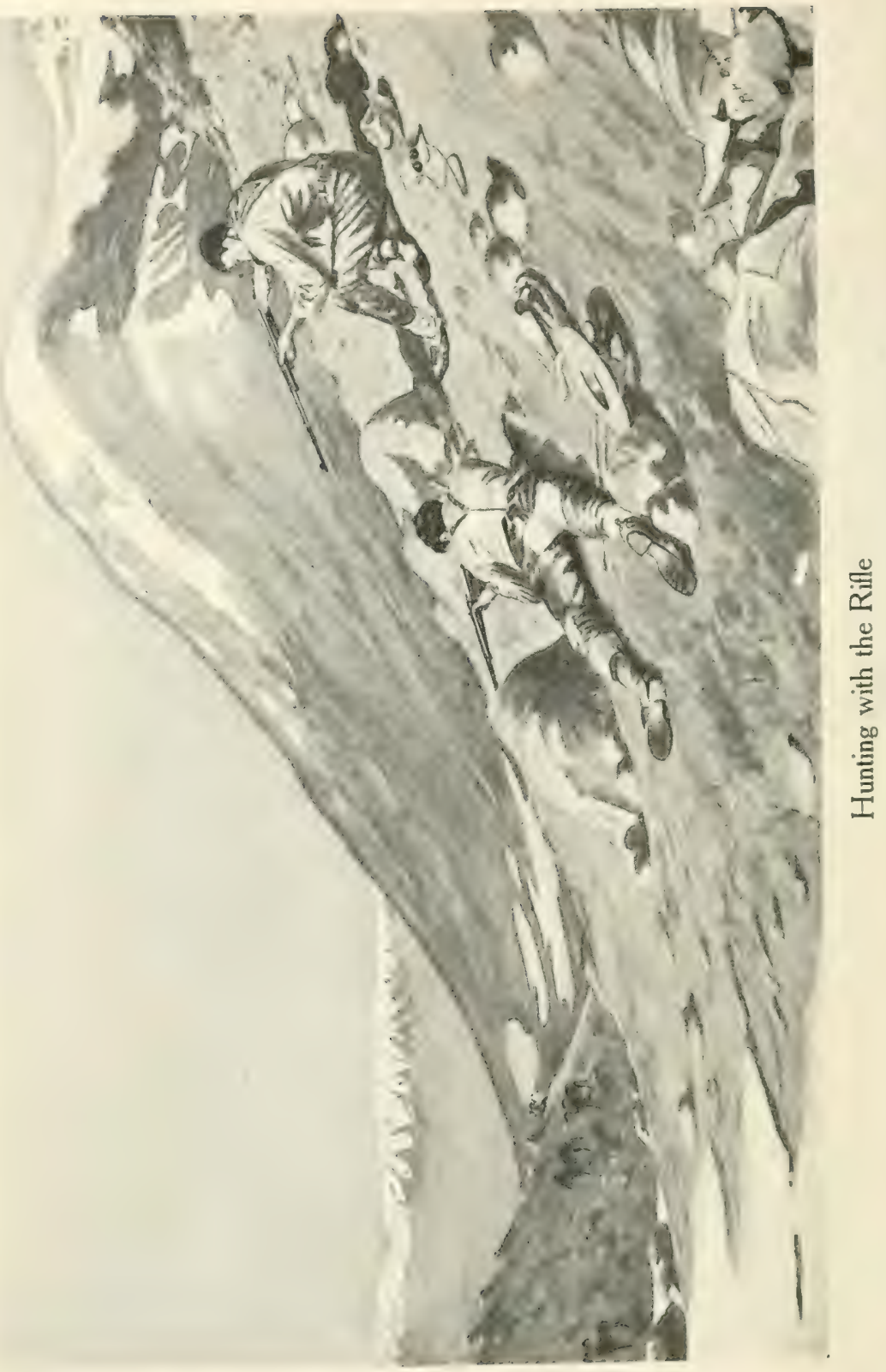


Target shooting can be enjoyed in almost any locality, and besides being an interesting pastime, it is a great benefit to veteran as well as embryo marksmen. The only danger in target shooting is that the marksman will become too slow and methodical in his movements for field shooting. The judging of distances is of great importance; and the hunter should never lose an opportunity to improve himseif in this respect.

The average big-game animal killed is shot at short range.

If it were not for the skill required in approaching them, and the fact that many of the shots are at rapidly moving targets, the sport would be far less interesting. The successful big-game hunter should be good at snap-shooting. Many people are of the opinion that small-calibre rifles are fitted only for target shooting.

They are very useful in the field, however, and in the hands of a skilled marksman are almost as deadly as the larger calibres. Even along the Alantic coast there are animals that make a hunting trip worth while. All through New England one finds that alert and interesting animal, the woodchuck. No country could be more pleasant than the rolling hills and shady apple orchards where the woodchuck lives. With a handshooting, small-calibre gun, one can spend many a pleasant hour stalking these animals. The target is small, as in woodchuck hunting the head

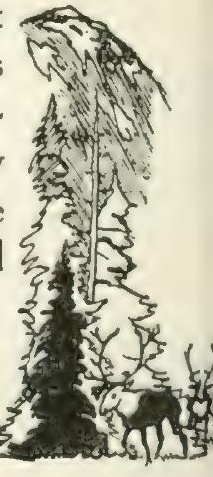


is the spot to aim for. If a woodchuck is shot through the body, he often reaches his burrow and escapes, unless the hunter can find a shovel.

Early in the morning when the sun first strikes the side hills, the woodchuck comes out of his burrow, and suns himself; and this is the time for the hunter to be afield.

In the lowlands we find the cotton-tail, and the successful rabbit hunter must exercise all the patience and care of the big-game hunter. Trailing rabbits in a fresh snow is fine fun, and the eye must be keen and the hand steady that brings him to bag. A rabbit that is not badly frightened will often stop running if the hunter gives a shrill whistle; and this habit has cost many a cotton-tail his life. In the central states, and in certain parts of the west, rabbits are very numerous. The big jackrabbit is also found, and furnishes splendid sport for the small-calibre enthusiast.

In the western mountains we find the woodchuck's big brother-Mr. Hoary Marmot. These animals grow to a large size, and living as they do, in very rugged country, offer many difficulties to the hunter. Their favorite haunts are the crumbled piles of debris at the foot of mountain rock-slides, and the steep mountain meadows where the bear and deer live. In Northern British Columbia the writer often ate these "rock-bears," and their flesh roasted over an open fire, is very palatable. Their skins are used by the Northern Indians in making 
blankets, and their fat makes a good gun- or shoegrease. Their sweet, long-drawn-out whistle echoes among the mountains from California to Behring Sea, during the summer time, and once heard will never be forgotten. The shrill whistle of a farm boy is enough to conjure up visions of glaciers and snow-covered peaks to a Western hunter.

In hunting the marmot the hunter often encounters larger game. The cougar invades the marmot country in the summer time, and proceeds to grow fat. They stalk the marmot among the stunted balsams until the deer begin to congregate in the lowlands. The cougar is an arrant coward, and easily killed; a .22 or .32 calibre bullet well placed, will prove as effective as a larger calibre.

The writer once hunted marmot in Northern British Columbia, in a country where that splendid animal, the mountain sheep, could be seen along the rugged cliffs.

The Canada lynx, and the bob-cat, also work towards the mountains in the summer time; and that savage little animal, the wolverine, roams among the rock-strewn hills.

Blue grouse feed among the mountain blueberries, and offer tempting shots as they alight among the evergreens.

On the high, wind-swept uplands, among the grey lichens and glacial drifts, the hunter finds the big willow ptarmigan, and the swift-flying " rockers." Both these ptarmigan are a welcome addition to the 
camp larder, and lead the hunter among beautiful surroundings.

In winter and early spring hawks and owls are often found in the qual covers near civilization.

The sharp shinned hawk in particular does much damage among our game-birds. In hunting these birds, the sportsman besides enjoying good practice with the rifle, can save many bird lives. There are a few of the hawks, however, who are not only harmless, but do a great deal of good, as they destroy quantities of rodents, and that outlaw among birds, the English sparrow. The man who wages war on the owl and hawk tribe, should thoroughly familiarize himself with their different characteristics, lest he kill a sheep in a lion's skin.

The wary fox is still found in good numbers near civilization, and is an ideal animal to hunt with the rifle. The fox is so well gifted in speed and cunning, that it is a hard animal to bring to bay. In overgrown farming country it is almost impossible to hunt him successfully. In certain localities, however, such as the north end of Long Island, or the far West, cover is scarce, and he sometimes falls a victim to the hunter's skill and marksmanship.

The time to still-hunt foxes near civilization is early in the morning, late in the evening, and on moonlight nights. All through the Northwest, and Alaska, foxes are numerous. Besides the red foxes other more valuable species are found. These animals are eagerly followed by the Indians, and 
many are secured by trap and gun. The Indian who can hunt the black fox successfully, is looked up to as a great man by his people. The character of our country in the Northwestem mountains is rolling and sparsely timbered. The difficulty is not in seeing foxes, but in seeing them before they see you, and approaching within range.

Indians as a class are poor marksmen, but some of these fox hunters become very good shots. If the hunter is well concealed, he can with favorable conditions, sometimes call a fox by imitating the squeak of a rodent.

Calling, by imitating the squeak of a field mouse, can be successfully practiced on owls as well as foxes.

The coyote, or prairie-wolf, is another animal that has withstood the advance of civilization. Traps, poison and guns have been tried, and yet the weird call of this prairie-wolf still echoes among the Western foot-hills.

The coyote is always found in fairly open country, and is a most interesting animal to hunt. Under ordinary conditions they are seldom killed with the rifle; but after heavy snows, and when they are overfed, they sometimes fall a prey to the still-hunter.

Besides holding his own on the Western plains, the coyote has enlarged his range. In Northern British Columbia, and the far West, they are found, where ten years ago they were unknown. Most of the shots in wolf hunting are at long range, and of course if the first is a miss, the 
following shots are at a rapidly moving target. Sometimes a party of cowboys will surprise a coyote in some narrow wash-out, or depression, and get very close to him before they are discovered. In these cases the cowboys' pistols come into action, and the coyote is represented by an indistinct grey streak headed for the horizon. The prairie-wolf is very fleet of foot. When cattle ranches grew common in the West, a bounty was put on wolves by the different states. Now-a-days, ranchmen often offer an extra bounty, and the "wolvers" as professional wolfhunters are called, sometimes make a fair living. But the interest in wolf-hunting is largely due to the exciting rides across the sage-brush flats, and the long shots at wolves, where the bullets throw up white puffs of alkali dust.

The big timber wolf ranges all over the West; but as most of the country they roam in is brushy or mountainous, hunting them would be a difficult matter.

In the coyote country one is liable to see the sage-hen. This bird is the largest member of the grouse family found in America. They offer splendid shots to the sportsman armed with a small calibre rifle, and due to their even flight they are sometimes killed on the wing by expert riflemen.

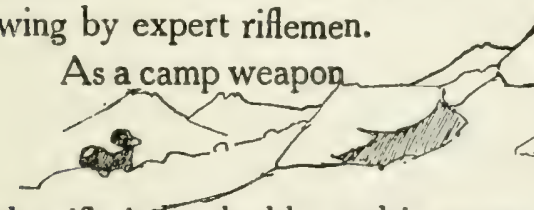

the rifle-is invaluable, and in everyday work the small calibres are the most satisfactory. The weight of ammunition is quite an item when travelling in the wilderness, 
and a .22-calibre for pot shooting is always useful. It often happens that ptarmigan, grouse, or ducks, are plentiful in big game country. When armed with heavy guns, the hunters pass them by, as they are afraid that big game may be frightened from the vicinity by the loud reports of the large-bore guns. In a case of this kind the .22-calibre will come in handy, as its report will carry only a short distance. The writer used a.22-calibre Stevens in the Cassiare Mountains of British Columbia. On this trip we killed all the ptarmigan and grouse we wanted, and the gun made practically no noise.

Besides keeping the larder full, it keeps a man in practice. In big-game shooting, the hunter goes for long periods without firing a shot. Even if successful he may only fire one or two shots a week, and the constant practice with the camp gun is of some benefit.

The killing of big game with the .22 rifle is usually due to chance. There are many cases, however, where big-game animals have been killed by this small arm. Even Mr. Moose, the largest wild animal found in North America, with the exception of the Alaska brown bear, has frequently been the victim. A prospector killed a moose near the Alaska boundary line. I was in the country at the time, and near the place where the moose was killed. The prospector came out of his cabin early one morning, and saw the moosea young bull-at a distance. A .22-calibre rifle was the only gun he had, but after a short stalk, he placed a bullet behind the moose's ear and killed it. 
The writer has met but one man, however, who has made a practice of hunting big game with the .22-calibre rifle. He is a citizen of Wrangel, Alaska, and does all his shooting with this small arm. He has been very successful, and has killed both moose and caribou. The hunting method he follows resembles that of the Indians. He approaches very close for the first shot, and counts on his accuracy with the small rifle doing the work instead of its smashing power. The only drawback to this calibre is that in unskilled hands it would cause much suffering among the animals hit, as the shot must be admirably placed to cause instant death or disablement.

The most distressing part of hunting is that occasionally a wounded animal escapes and dies a lingering death. The hunter should never allow an animal to die in this manner. I have seen an uneducated Indian travel mile after mile in pursuit of a wounded animal for no other reason than to end its sufferings.

This crime happens less among real wilderness hunters than among sportsmen; and it should be carefully guarded against.

When the hunting days are over, and the old gun is resting above the fireplace, our ideas on hunting change. The successful kill becomes merely an incident of the hunt; not a lasting pleasure. The living memories are of the long, wild days in the open, the glare of the Northern sun on ice-coated

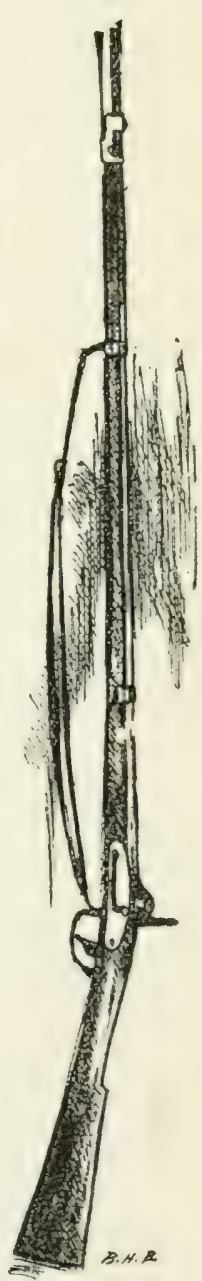




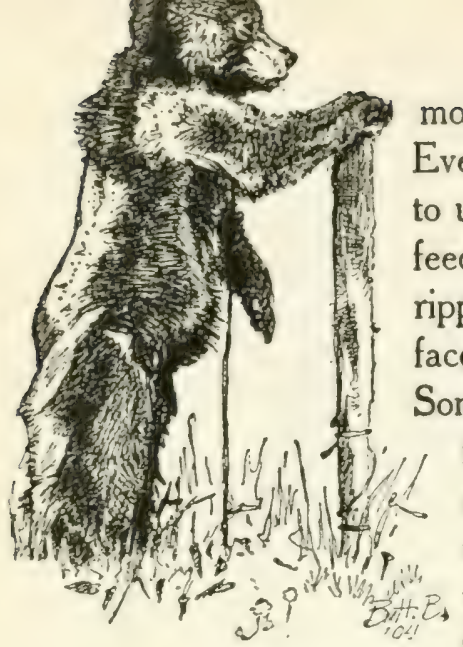

mountains, and the sound of rushing water. Every camp we have made comes back to us; once more we hear the pack-horses feeding in the dusk, and the trout brook rippling among the cotton-woods. The faces of old camp companions return. Some are faces of friends grown rough from the wild life; others, narrow-eyed and bronzed, are the faces of wilderness men-low-voiced Indians, and whites with no home but the mountains. Once more we feel the pack and "tump-line," and stagger weary into camp as the sun dips beyond the ranges.

But there is no sting in an arduous task well done, and the memory of cold and sleet-numbed bodies brings no suffering.

The man who has never pressed a rifle-butt to his cheek, does not know himself. Our wild side, handed down to us from the stone age, can only be aroused by warfare or the excitement of the hunt. Life in the wilderness is arduous, savage, and hard; but it is free as the mountain wind, and as open as the sky. The wilderness man is rough; but he does things with his hands and by the sweat of his brow.

$\mathrm{He}$ is a knight of the pack-strap and gun, and his generosity and courage are as boundless as his kingdom. And so when our thoughts drift backward towards the old days, they rest lovingly on the battered rifle-the "open sesame" of the wilderness, and the out-door man's best friend. 



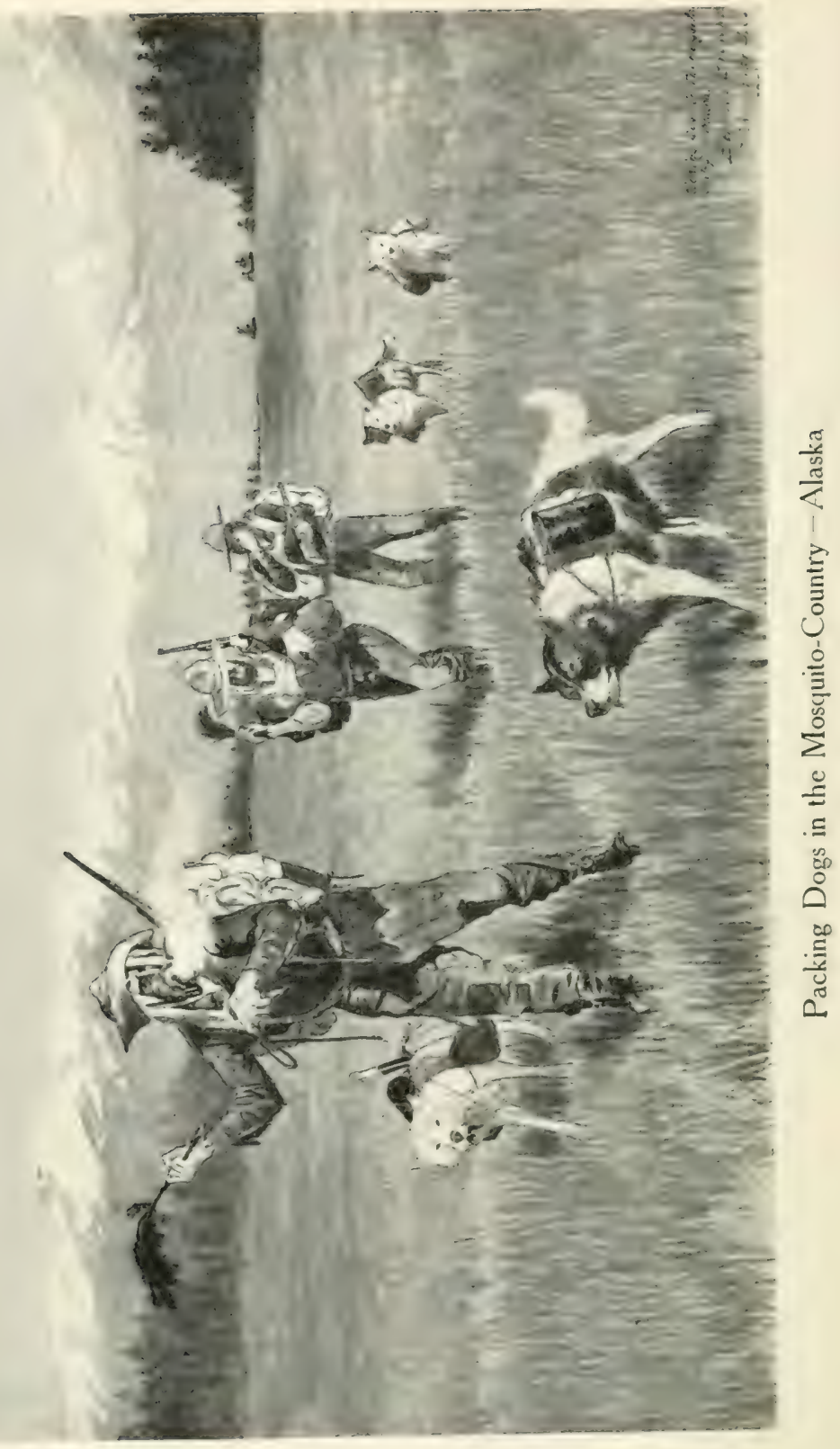




\section{CHAPTER III \\ $x$ \\ The Shotgun}

$7 \mathrm{HE}$ shotgun now-a-days is purely a sporting arm. Being a short-range weapon it is of little use in big-game shooting in open country. By this I do not mean that the shotgun does not shoot hard; at short ranges it is a powerful weapon, and loaded with ball or buck-shot, at moderate distances, it is as deadly as the rifle. It is the extreme long range of the modern rifle that has relegated the shotgun to the position of a smallgame arm.

The gauges commonly used in shotguns vary from the light 16-gauge, up to the heavy 10 -gauge duck guns. The 16-gauge is a very light gun, and it is usually used for quail and snipe shooting; but some good duck shots use it. It is a satisfactory gauge for upland shooting. The 12-gauge is the most popular gun used, as it is strong enough for any game, and is still light enough for quick shooting.

The 10-gauge is purely a duck or goose gun, as it is too heavy to use in snap shooting in thick cover. 
There has always been a controversy on the relative merits of the 10,12 and 16-gauge guns. While the 10-gauge throws more shot than the 12 or 16 , the matter seems to be entirely one of individual tastes. Some men can kill more with the 12 or 16-gauge, due to their lightness, and the ease with which they can be handled.

Personally, I have never seen a 10 -gauge outshoot a 12-gauge in the field, even at ducks and geese: and I have been on many hunting trips where both these gauges were well represented. Despite the modern use of the shotgun, it is a splendid wilderness arm. Its only drawback is the weight of the ammunition.

As the hunter can use either shot or ball, he can live off the country with ease when the game is little hunted. In shooting for the pot a man can usually kill enough ducks or ptarmigan with a shotgun to supply a number of men with food.

The shotgun is accurate up to 80 yards, when loaded with ball, and will prove satisfactory in hunting big game.

As our modern shotguns are usually choked, it is dangerous to ball without first measuring the size of the barrel. A good way of making your own bullets is as follows:

Drive a wad through the barrel, until it is within an inch of the muzzle; then pour in enough lead to make a distinct mould. Send this piece to a bullet-mould maker, and have him make a 
round mould of the same size. Now, as a bullet the same size of the mould would be heavier than necessary, you could lighten it in this manner. File a notch in the jaws of the mould large enough to fit a pin. When you pour lead into the mould, insert a pin in the notch, with a small round piece of cork on the end of it. This will make the finished ball hollow. When loading the ball in a cartridge, place the heavy end so that it will leave the muzzle first.

This load will prove satisfactory on large game. In our Northwest the small game hunter often sees large game while hunting, and is at a loss to know what to do. In a moderately choked gun the "split Shell" can be used, and will prove a good charge for deer, black bear, etc. The best feature of the split shel! is the rapidity with which it can be arranged, and the fact that the hunter needs nothing but a small knife to change his harmless shotgun into a big game arm. The way to cut a shell is to break the divisions through the wads that separate the powder from the shot. On looking at a shell we can see a slight swelling between the powder and shot; near the powder end of this swelling is the place to cut, and a little practice will be necessary to get the best results. After the shell is cut in two it is placed in the gun and fired.

The shot end of the shell travels in one piece, and at a distance of 80 yards will penetrate well and make a terrible wound. 
Care should be taken to leave a little piece of the shell uncut, as it will keep the shot end of the shell from sliding down the barrel prematurely and bursting the gun. The first time I tried a split shell I practiced on a target nailed to a tree, until I found where to cut the shell to keep it from breaking before it hit the mark. A few days afterward I was duck-shooting, and a large flock of blue-bills lit about 100 yards from my stool. They proved

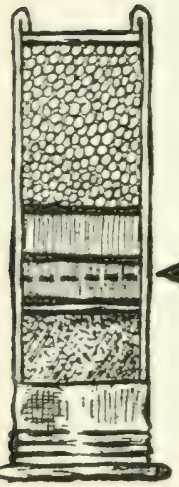
so attractive that several single birds that would have come to my decoys swung off and joined them. At last I decided to scare them away, and thinking of the "split-shell," I shot one at the flock, aiming high, and to my great surprise, I killed one.

There is danger, however, in shooting a splitshell in anything but a moderately choked, or cylinder bore barrel. Buckshot are very satisfactory for big-game hunting; they carry well, and have a fair penetration; but big game hunting with the shotgun will never be popular except in a very bushy country, as little skill is required to hit a large animal with shot, at close range. If food is scarce the shotgun is indeed a valuable possession.

For field shooting the most popular gun is one that has a cylinder right, and a moderately choked left barrel. Ducks are killed at longer ranges than upland birds, and their feathers are thicker; so a gun with a moderately choked right, and close choked left barrel, is used.

Due to modern methods and machinery, there has been a long step made in the manufacture of firearms. Besides improving in construction, they 
are more reasonable in price, and are put through the hands of experts before leaving the factories.

A great deal has been written on how to shoot with a rifle or shotgun. Marksmanship is a fascinating study, and is always of interest to the sportsman; but the writer's experience has been that the more you use a shotgun the fewer theories you have about shooting.

Shooting with a shotgun differs from rifle shooting in certain particulars. Where rifle shooting is methodical calculation and precision, shotgun shooting is guesswork and quickness. When a grouse thunders upward through the autumn leaves, the sportsman has a dim blur, occasionally completely hidden, for a target. Sometimes he knows where he aims, but usually he pulls the trigger when he "feels" the gun is pointing correctly.

If a companion "pulls down " a high, strong flying mallard, and you ask him how much he led the bird, he will answer: "about six feet;" but he did not really measure the distance when he shot, but discharged his gun when he "felt" that the gun was aimed currectly. This guess-work or judgment enters largely into shotgun shooting. Many men shoot with both eyes open, paying more attention to the mark than to the gun.

One celebrated Western wildfowler shoots as easily from the waist, or hip, as he does from the shoulder.

Shooting, with him, is a "feeling;" he has no theories. When he feels his gun is pointing right, he "cuts loose."

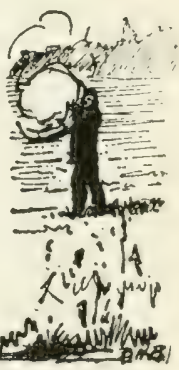


The beginner must "paddle his own canoe" in learning to shoot. He must practice faithfully, and trust in his own judgment; as no one ever learned to shoot from reading books. One thing is absolutely essential for good shooting, and that is a gun that fits the gunner perfectly. Men are built on so many different patterns that one gun will not suit every one.

Your gun should be so balanced that when you put it to your shoulder it will "come up" exactly on the mark aimed at. The only good rule in wing shooting is to keep your gun moving with the bird until after you shoot.

If you have a cross shot at a fast-flying bird you will aim sometimes ahead of it. If you stop swinging your gun for a fraction of a second, on pulling the trigger the chances are that you will shoot behind the bird. As ducks are said to attain a speed of over 75 miles an hour, one can readily understand the importance of swinging the gun evenly, and the slightest delay in pressing the trigger will cause a miss. In upland shooting the hunter has many quartering, or straight away shots, in the open. In these cases, he can take his time, and hold as close as he wants to; but in swift cross shots, in heavy winds, he will have to rely on a kind of instinct, that tells him when to pull the trigger.

One of the unexplainable things in duck shooting is, that at times a good shot will be unable to hit anything. He gets "hoodoed;" duck after duck goes by, without one staying behind to warm the game bag. Usually this "spell " does not last 
long, and the hunter's experience begins to tell. The reverse is also true; sometimes a novice will "crumple up" bird after bird like a veteran until his luck changes. The man who has hunted exclusively with a shotgun, always finds it hard to change to a rifle. As a rule he "over shoots" at first, as he forgets the rear sight; but at running game, his knowledge of wing shooting comes to his aid.

The writer once hunted big game with a shotgun expert who seemed unable to hit anything with a rifle, until it began to move, and then he would shoot very well.

Trap shooting is a pleasant sport, and if it is indulged in during the summer months, will help a man considerably when he begins to shoot in the field. While trap shooting differs in many ways from field shooting, it will help the sportsman in judging speed and distances.

A shotgun is comparatively easy to clean. The barrels are large and smooth on the inside, and the cleaning rod can be inserted from either end; but keeping a gun in good condition requires constant watchfulness. The right time to clean a gun is immediately after using it. To get a gun properly clean, it should be thoroughly overhauled at intervals of a day or two, for about a week. This should be done always when you are putting a gun away for a long time.

It seems as if there was moisture in the metal that comes out and rusts, after a gun has been cleaned. Some men oil their guns thoroughly before putting them away, but this is risky, unless 
the oil is of the very best quality. It is safer to have the gun perfectly dry, and the barrels stuffed at both ends with a clean cloth.

Newspaper is useful in cleaning guns; it removes rust, when used with oil and lots of elbow grease.

Stevens Odorless Gun Oil is about the best gun oil made for both metal and wooden parts. It is a good plan to cover a gun with oil before going duck shooting, but the gun should be thoroughly wiped and cleaned after it is used, as it will be covered with sand and dirt.

The beginner will attribute many of his misses to defective ammunition. He often begins to load his own shells, and keeps intricate accounts of the money he saves. It does not matter how long he works, so long as he saves ten cents' worth of powder.

Of course it does him no harm, except the time wasted, but now-a-days shells are so cheap, and so much better than the average man can load, that it does not pay to experiment.

Shooting is a sport that offers untold pleasures to those who follow it; and as most of us seldom get a chance to hunt big game, the shotgun becomes our favorite arm.

With a good dog and gun, a man can wander of into the country and lose himself in the beauties of nature; worry drops from his shoulders, and he is once more a boy. So long as there are trout streams, and rolling hills where the grouse and quail hide, there will be men who love far more a day well spent with nature, than money and the roar of cities. 


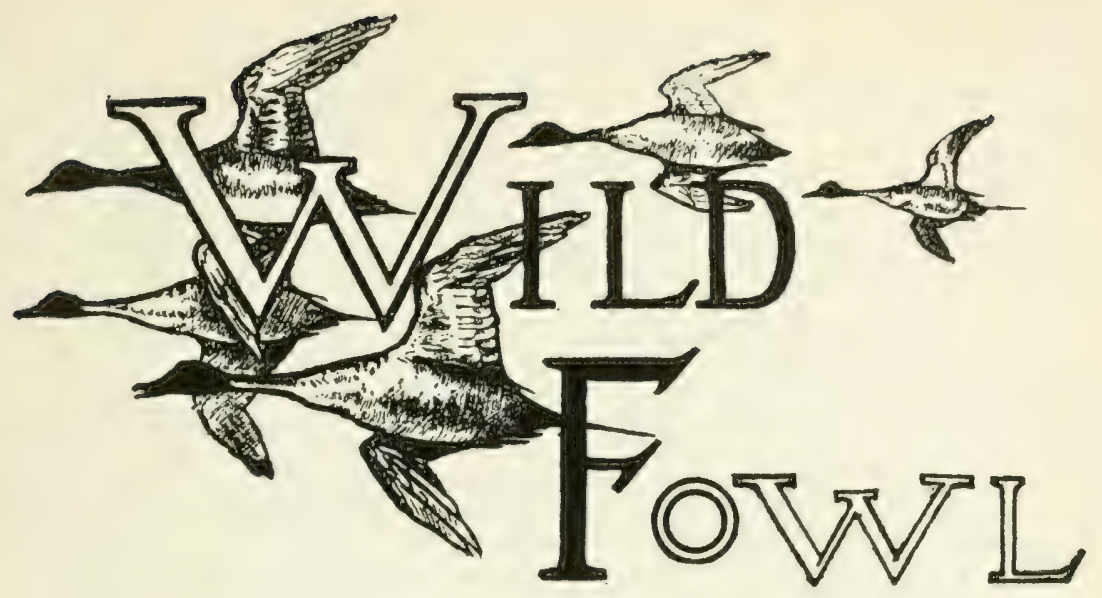

CHAPTER IV

\section{5 \\ Wild Fowl}

WY HEN the golden leaves of Autumn are $^{\mathrm{HEN}}$ covering Mother Earth for her long sleep; when the woodchuck and squirrel have prepared their snug winter homes, and the first cold winds have warned the wood folks of winter's approash, the long $\mathrm{Vs}$ of water-fowl start for their warm haunts in the Southland. Of all the movements of wild things, there is none more impressive than this grand, irresistible migration. All summer the lakes have been deserted, save for the marshwren, and blackbird. But with the approach of winter a change comes over the land. 
From the dark pools at twilight comes the soft calls of the drake mallards, and from the open waters the whistle of widgeon. Night by night the sounds increase, until the air resounds with the clanging calls of geese, and the hissing of feathered phalanxes.

This is the time when the devotees of the blind and decoy hie them to the marshes.

It is possible to give the young hunter going on his first hunt a few suggestions that will be of value in a day's sport. But the really important features he must learn by experience.

The most vital factor in a successful shoot is a good knowledge of the habits of wild fowl; as here conditions change so that even the veteran gunner is sometimes at fault. Every move made in a day's duck hunting is based on what the hunter thinks the game will do on that particular day; and if his reasoning is sound, a heavy game bag will be his reward.

When the novice for the first time crawls into a boat in the wee small hours, to row to the duck grounds, he usually wishes that he hadn't. It is pitch dark, of course; he hasn't enjoyed his yuickly cooked breakfast; and the cold makes his teeth chatter.

If there is any wind, his sorrow is unlimited: and yet this very wind-unpleasant as it may beis what the veteran duck-hunter wishes for above all things. For it makes the birds fly low; then it 
brings them from the open water into the flats and inland ponds; and lastly, it animates the wooden decoys.

The first thing to be done on reaching the hunting ground is to decide on a good place for a blind. Where clubs own large tracts of land that are reserved for the members, the blinds are quite substantially built, and the members draw lots for their positions. But if we are hunting on large, unprotected marshes, the choosing of a blind is most important.

First, we must have water to float the decoys; and also the boat, it there is no dry land to shoot from. As duck, though flying high, will usually follow a waterway, if is a good plan to keep close to some slough that runs across the marsh. The blind should be built immediately on arriving at the chosen spot. It should be low, and not too large, as of course the less attention it attracts, the better. After placing all the necessaries in the blind, the decoys must be put out; and there are many ways of arranging them. Then if the blind is on land, the boat must be taken to a distance, and hidden. All these preparations must be completed before the break of day, as the early moming and evening shooting is usually the best. 


\section{BLINDS}

It is frequently the case, where wild fowl are numerous, that nature has provided blinds for the sportsman.

Willows, and other shrubs, often grow near the ponds and sloughs where ducks congregate; and these natural blinds, with a little improvement, are usually very satisfactory. The duck hunter, however, must be prepared for every emergency; and often the best shooting will be had where there is no cover.

There are several ways of making blinds; and two of them have helped me on many a successful hunt. By cutting up and sewing together some gunny sacks; get a piece of sacking about $12 \times 31 / 2$. Nail the ends into two sharpened sticks. Then with heavy twine make many loops in the cloth. These loops will hold the dry marsh grass or leaves that you use to cover the blind.

On arriving at the marsh you make a circle of three or four sticks, according to the size you wish your blind to be. Then wrap your gunny-sack blind around them, and fasten it in place by pushing the sticks that are nailed to it, into the earth. Arrange the height and size of blind to suit your pur-

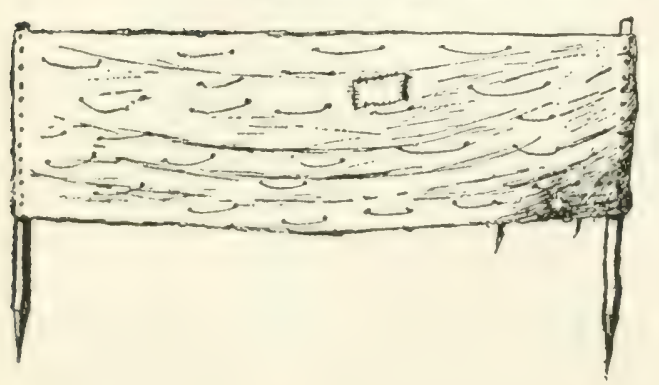
pose, and then pull handfuls of marsh grass through the loops in the blind. 
This blind, when folded, makes a good cushion for a boat seat, and takes up very little room.

Another very simple way of making a blind, is to take a strip of chicken wire, and after staking it in the right position, weave dry grass through the openings.

\section{4. \\ DECOYS}

Hunting without decoys robs duck shooting of its chief charm. In shooting over a stool the ducks come of their own free-will, to the hunter.

There is no sight more thrilling in bird shooting than that of a flock of wary canvas-backs circling closer and closer to where the hidden sportsman has placed his stool. Here, again, the knowledge of the habits of water fowl is necessary.

\section{展 \\ NUMBER OF DECOYS}

Men differ radically concerning the correct number of decoys to use, but if the hunter follows the hints of the wild birds themselves, he cannot go far wrong. In the open water where birds congregate in "large rafis" to rest, sink boxes are necessary, and in this kind of shooting a stool of 100 or more decoys may be used.

Inland, where the ducks fly in separate flocks, fewer decoys are needed, but there must be enough

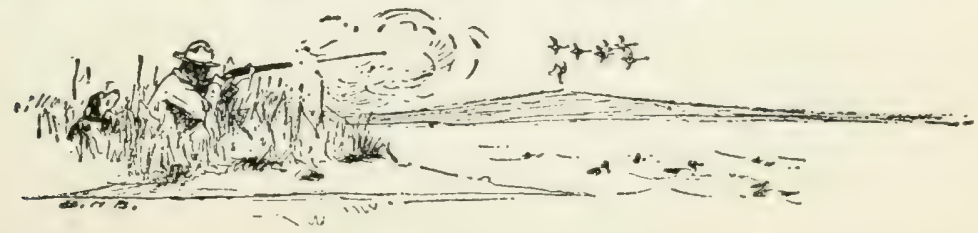


to make a good showing. About 20 decoys is a good number for shooting in inland ponds, as the number can be easily managed.

In buying or making his decoys, the novice wonders which of the many types of ducks to take as a model. And, here, again, the stool depends on the kind of hunting they are to be used for.

In open water, where diving for food is necessary, canvas-back, red-head, and berat (or blue-bill) decoys are the best, as any of these species will decoy freely to each other. Also golden-eye, bufflehead, and braut, will swing in to a school of diving ducks.

But inland, in the shallow, fresh-water ponds, mallard decoys are generally accepted as the best type, as widgeon, pin-tail shoveller, and teal, will come to a mallard stool. As a rule, in inland shooting the sportsman does not see much of the diving ducks, such as canvas-back, red-head, blue-bill, etc., and the same rule holds good in open or salt water shooting, with the surface or shallow feeders, such as mallard, widgeon, and pin-tail.

\section{\& \\ MIXED SHOOTING}

But in cases where good mixed shooting is enjoyed, it is possible to arrange a stool that will be attractive to all species. 
A very successful method of arranging a stool for mixed shooting is to use a stool composed of both diving and surface ducks. The mallard or teal decoys should be placed along shore, among the lilypads, or grasses, while the canvas-back stool should be placed in a compact flock in open water. I have on one or two occasions had excellent shooting over a canvas-back stool arranged in the form of a V; but whether my success was due to this particular formation, I am unable to say.

In early morning shooting it is a good plan to spread the stool, placing some of the decoys in shallow water as if they were feeding. In the middle of the day there is not much shooting as a rule, and a big stool in open water can be seen further, and often bring in a few birds. In putting out a stool, always put it up wind from your blind, as in alighting, all ducks fly against the wind, and in swinging the stool they will pass close to your blind.

\section{4 \\ FITTING OUT A STOOL}

In fitting out a stool it is necessary to know where you are going to use them, as the anchors and string must be heavy and long enough for any conditions. The best method of making the anchor fast, is to take enough fish-line (about half the size of cod-line) and make it fast to one decoy with a loop of leather. The leather should be nailed on 
with some non-corrosive nails. This rig will save you many days, as the anchor string won't rot.

Any piece of lead will do for an anchor; but it is better to make miniature mushrooms by pouring hot lead around the ends of a twisted wire, as this rig will be less liable to tangle.

In salt water wild fowling in the far Northwest, very long decoy strings are needed, as the fall and rise of tide is very great.

It is a good thing on buying a stool to brand your name on the bottom of each decoy, with a hot iron, as all decoys are much alike, and, like an umbrella, are often mistaken for public property.

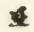

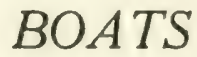

There are many styles of duck boats, and all of them are good. The principal necessary features are lightness, strength, and stability. As most wildfowl shooting is done on marshes or flats, the boat must be shoal draft. It should be large enough to hold two men, a dog, and a medium stool. As the best shooting is enjoyed in the autumn, when fierce storms are apt to spring up at any time, a boat with a good free board is necessary, or if it is decked over, a good combing around the cockpit is a factor of safety. A long painter will often come in handy, also a small keg of fresh water. 
And in inland shooting particularly, a pole besides the oars, is often useful. Another good wrinkle is to have the knees of your boat the same width as the shells you use; for then when shooting from your craft, you can use the inside strips for a shell rack.

\section{s \\ CLOTHES}

The clothes used on a duck hunt should be of very heavy, warm material, but the outside layer (and this will save you many a bird) should be of a protective color. Hip boots are necessary, as you will often want to kneel in shallow water. If you want gloves, get them large, so that you can throw them off by swinging your arm down quickly.

\section{\$ \\ GUNS AND AMMUNITION}

More is demanded of a shotgun in water-fowl shooting than in any other kind of hunting. The birds killed are large and strong; and their feathers are so thick and evenly grown that they amount almost to a shot-proof covering. A sound familiar to all duck hunters is the rattle of shot on the hard feathers of a high flying bird, which disappears in the distance none the worse for the lead shower. 
Men differ as to the correct gauge for a duck gun. Some use the 10-gauge; others, the 12-, and occasionally you find a man armed with a 16-gauge.

The writer's experience has been that the middle course is wholly the best, and that a 12-gauge, 32-inch barrel gun, medium choke right, and close choke left barrel, will stop any bird that flies under any ordinary conditions. The 10-gauge is too clumsy a gun for anything but wild-fowl shooting; and the 16-gauge is a little too light for ducks and geese, though it is an excellent upland gun.

4

\section{AMMUNITION}

When smokeless powder first appeared, many old, experienced sportsmen continued to use black powder, claiming that it was superior in a number of ways to the smokeless. But now things have changed. The roar of the old drive duck gun no longer echoes across the marshes, and from far and near comes the sharp, barking report of the modern breech-loader. Smokeless is a very quick powder, and in using it the gunner can hold much closer to his bird than with the black powder.

As now-a-days ammunition is loaded so cheaply and evenly, it does not pay (unless one is very particular) to load one's own shells. Besides, smokeless is more difficult to load than black powder, and the chance of accident is greater. 
This is reason enough for a novice to let smokeless alone, until he has learned by experience just what charge he wants.

\section{5 \\ SIZE OF SHOT}

Many different sizes of shot are used in duck shooting, and all are satisfactory, from the market hunter with his 10-gauge and No. 2s, to the sportsman with his No. 5 s. In fact, the size of shot depends largely on where you are hunting. If it is late in the season, and you are hunting on salt water, you will need heavy shot and strong loads, something in the neighbornood of $3 \mathrm{~s}$ or $4 \mathrm{~s}$. But early in the autumn, when the birds are not in full feather, $5 \mathrm{~s}$ or $6 \mathrm{~s}$ will do. The writer has used $7 \mathrm{~s}$ and even $8 \mathrm{~s}$ with success, early in the year; but ordinarily, this shot would be too light. Every one who has been afield, can remember almost impossible shots they have made. Sometimes you will "crumple up" a strong flying canvas-back at an impossible range, with a charge of $8 \mathrm{~s}$; and again, the heaviest shot seems too light. It is a good plan when going on a long hunt to take shells loaded with several sorts of shot. The smaller sizes will come in handy for killing cripples or an occasional yellow-leg, or Wilson's snipe.

It is remarkable how a load of No. $8 \mathrm{~s}$ will kill a cripple, when it is half under water, and at long range, and yet at flying birds they are unsatisfactory. 


\section{HUNTING}

One of the most pleasant features of waterfowling is the great number of methods open to the hunter.

Ist, there is decoy shooting, where the hunter lies in wait for the bird with a bunch of decoys.

2nd, there is pass-shooting, where the fowler stations himself between two large bodies of water, and shoots the water-fowl as they change their feeding grounds.

3rd, there is point-shooting, where the hunter kills his birds as they are following the shore of lake or sea.

4th, is the stalking, or "walking up" of the ducks as they are feeding in some marshy lake or slough. All these methods combine many variations, and afford unlimited pleasure to the sportsman.

\section{\& \\ SHOOTING OVER DECOYS}

There is much to be learned in decoy shooting besides the putting out of the stool and making the blind.

One of the most difficult things to master is telling when a flock of ducks has approached as close to the blind as they are going to. Often a bunch will swing around the decoys at long range, and fly away, only to make a large circle and come sweeping back close to the hunter. He who can read 
the minds of ducks by their actions, must spend many a day on the marshes. At times some birds will swing in, giving the hunter a long but possible shot. If he hesitates for a minute, his chance is gone; and unless they turn again, he must sit sadly while the flock fades to a dim line in the distance. The greatest fault committed by beginners, however, is that of shooting too soon; and many a splendid shot is lost in this way. There is always a moment when the decoying birds hang for a fraction of a section above the stool, or waver between a desire to alight, and a suspicion of their painted dummys. A wonderful picture they make with their graceful necks outstretched, wings bowed, and feet hanging; and this is the time when the hunter carefully picks out one chosen bird, and swings the old gun into line.

The beginner will often find to his cost that no matter how full of birds the air looks, the holes between them are still more numerous; and that no matter how large the flock is, each duck shot at should be singled out clearly as the gun is coming to the cheek.

\section{(3) \\ CALLING DUCKS}

It is possible for the hunter to develop some skill in the use of a duck call. While the call is not infallible in bringing in birds, when used judiciously, it will sometimes turn a wavering flock to the stool. Great care should be taken in the use 
of the call, or it will serve rather to frighten than to attract the wild birds.

When a flock is at a good distance, a few loud "quacks" on the call will often start them towards the stool. As soon as the flock has seen the stool and started towards it, the calling should stop, or at least be very subdued. Ducks when feeding often carry on a low, chattering conversation among themselves, and many wild fowlers imitate this guttural chattering sound up to the time that the birds are within gun shot. I have often noticed that ducks are not frightened much by the human voice, when decoying; and have even seen them come into the stool when the unprepared hunters were laughing heartily at some joke. The young sportsman, however, should take much pains to keep still and well hidden, as the less done to take the duck's eyes from the decoys, the greater the chance of success.

\section{PASS SHOOTING}

Point and pass shooting are very much in the same class. In both cases the ducks fly by the hidden sportsman on the way to some feeding ground. In point shooting decoys are used but merely to attract the attention of the ducks and bring them a little closer to the hunter. Ducks seldom if ever come in to the decoys on an exposed point between feeding grounds. This form of hunting is interesting chiefly on account of the skill needed to stop the hard flying birds at long range. It is not my 
purpose to go into the speed attained by flying ducks, as I have never had a chance to drive a flight.

However, I have seen our slow flying ducks pass with ease a train in which I was riding, that was going at the rate of 60 miles an hour.

Now, in point or pass shooting, the birds are travelling with a good start, under a full head of steam, and as the shots are of good length, the man who can get a fair average must be able to shoot well.

Sometimes, in the Western States, the ducks move in such numbers that pass shooting requires little skill. Where there is a hill between two large feeding grounds, the ducks will often skim over it without rising to any extent in the air. And at dusk the hunter is sometimes afraid to stand on the crest lest one of the feathered bullets should strike him.

At times, on good passes at the height of the evening flight, the wild fowl will be in such numbers that their wings make one continuous hiss, as flock after flock pass to their resting grounds.

\section{$\mathbf{3}$ \\ "JUMPING" DUCKS}

Flushing, or "jumping" ducks, is a very pleasant sport. This method of hunting comes as a relief to the hunter who has been cramped in a blind all the morning. While the morning flight is 
on, better success can be had with a blind and stool ; but as the flight begins to slacken, the hunter marks down the birds that alight near him, and goes after them on foot. The two things necessary for success in this kind of hunting, are: caution in approaching the birds, and experience in rising shots at long range; as the birds are easily frightened, and rise so rapidly that the novice invariably shoots too low. A very successful method of "walking up" ducks is for two hunters to work together, about 60 yards apart. In this way many good shots are secured, and the birds are more easily found and retrieved.

\section{4 \\ SINK-BOX SHOOTING}

Sink-box shooting is the least attractive form of wild-fowl shooting. In the first place, the hunter, being marooned in an anchored box, is dependent on others, and cannot change his hunting ground. The shooting is also done on one duck's resting grounds, in open water, and for this reason is, in some States, prohibited by law.

Sink-box shooting, however, for men who live in large cities, is fairly good sport. Due to the difficulty of handling and keeping this outfit in good condition, it is usually owned by some professional hunter, who rents the box and stool to the sportsman. A certain degree of perseverance and hardi- 
hood is necessary in this kind of shooting, as a sinkbox on a cold day, with a stiff breeze blowing, is not very comfortable.

The blind is nothing but a box sunk to the

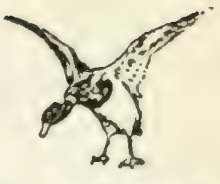
level of the water by decoys made of metal, and by the weight of the hunter. Around the box are wings of canvas that float on the waves and keep the wash from entering the sink-box.

A large stool is usually used, and in favorable conditions large bags are made.

The birds killed are retrieved by a hired helper who waits down tide or wind and picks up the floating birds.

In case of stormy weather the hunter signals to his helper, who comes and takes him off, as the box cannot stand much sea.

Most of the ducks killed in sink-box shooting are the salt water or diving varieties.

\section{$+$ \\ GOOSE SHOOTING}

Goose shooting stands by itself in the pursuit of fowl.

Although ducks and geese are often found together, the best goose shooting is had on the dry, flat wheat fields of the far West, and Western Canada, where, due to the lack of water, ducks are not numerous. 
While there are several ways of hunting geese, the most successful is that of digging a hole in some wheat field where the birds congregate to feed, and then shooting them over decoys.

As the hole is dug, the earth is removed to a distance, and scattered about so that it does not show. The rim of the hole is then lined with a ridge of wheat stubble, and with the decoys in place, is ready for use.

The hunter faces in the direction from which the birds are expected. The geese spend the night on some large body of water, often at a great distance from the wheat fields. They fly to the feeding ground, and after getting their fill, return to their resting grounds. The decoys used in this kind of shooting are flat, and cut out of sheet metal of some kind. As the blinds are too small to admit of holding many dead geese, they are usually staked out as soon as shot, and answer for decoys.

This method of using dead birds as decoys may be employed in duck shooting as well as in goose shooting.

A small stick sharpened or split at one end is all that is necessary.

Take the sharpened end and push through the duck's head from underneath; shove the other end into the ground until the duck assumes a natural pose. If there is water, the stick must be longer; and if a split stick is used, the duck's head is inserted into the opening. 



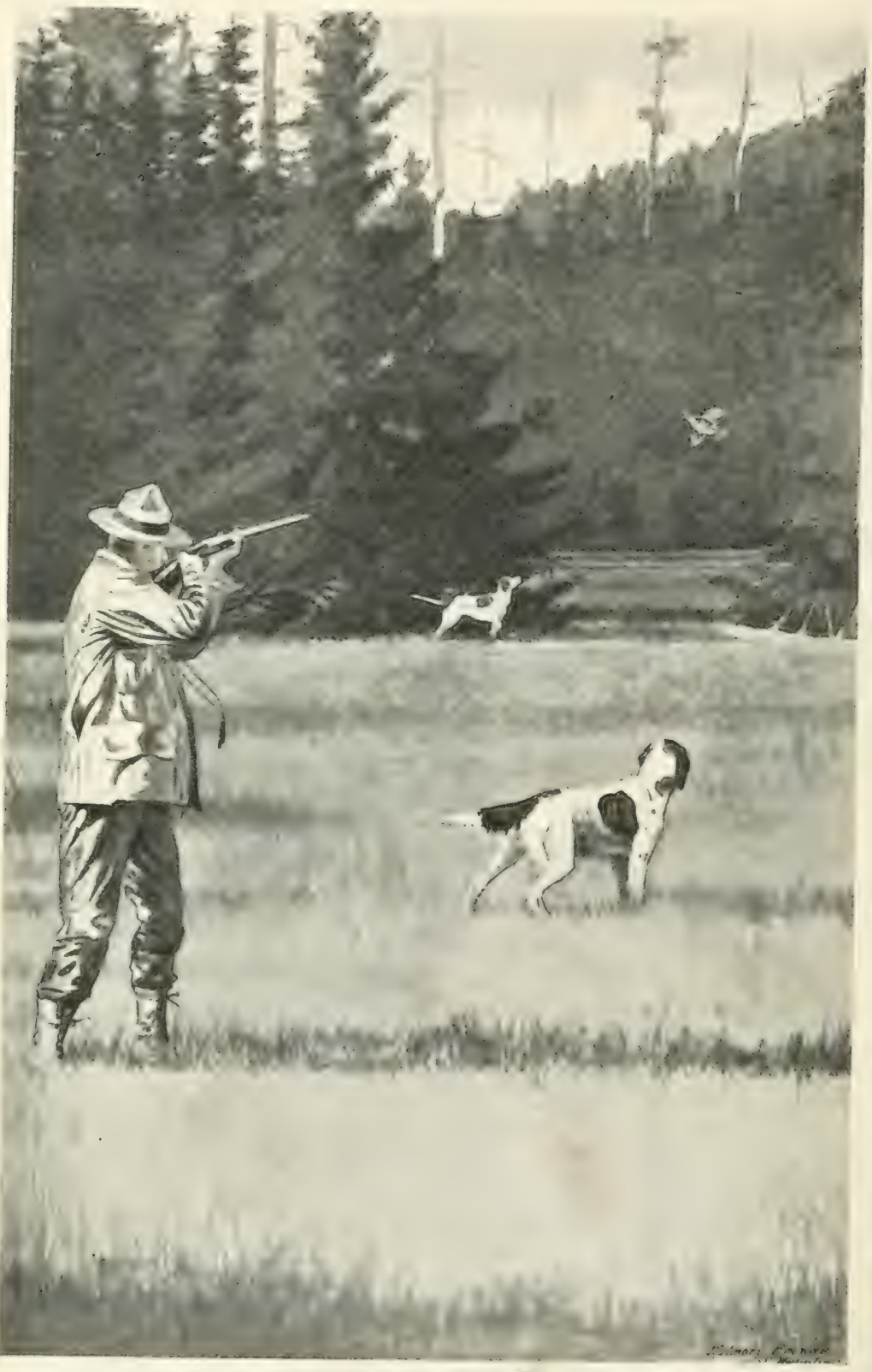

Blue Grouse Shooting 

work. In all other bird shooting dogs are used principally as retrievers, but in upland shooting they do most of the work. This sport is at its best near civilization, as the birds are usually found in farming country.

Ducks flourish in the bleak, northern wilderness, but not so our upland game birds. Besides the food they get from the grain fields, their natural enemies are fewer.

\section{GROUSE AND WOODCOCK}

Probably no two upland game birds are better known and appreciated by sportsmen than the grouse and woodcock. They combine to a high degree those traits that make them worthy of the hunter's skill. The woodccck is a recluse, and his range is small; but wherever there are trees and running water, from the Atlantic to the Pacific, we find the ruffled grouse or his brothers.

Their movements seem shrouded in mystery. To-day, the alder thickets may be deserted, save for an occasional grouse ; and to-morrow the hunter's bag will overflow. In Massachusetts there are, as a rule, two flights. The first, coming about the time of the first frost, is composed of the birds that have gone far north to breed; the second is the Northern flight. The birds composing the first flight are found in the alders and bottoms; but the second flight birds, strange to relate, seem to prefer 
the hillsides and oak thickets. The woodcock's whereabouts depend so largely upon climatic conditions, that the successful hunter must be a careful student of their habits, and thoroughly familiar with the country over which he is hunting. A man might live for years within easy reach of a good woodcock cover, and not see a bird. The range of the woodcock is very small compared with that of our other game birds. The principal flight is along the Atlantic States; and they are never found in the West. The woodcock probes for its food with its long bill, and the holes or "borings" that they make while feeding can be seen in the soft mud in the bottom lands.

The woodcock has a very tender skin, and is easily killed; its flight is short, and it can often be followed and flushed again if it has escaped from the hunter. The thick brush is what makes suc-

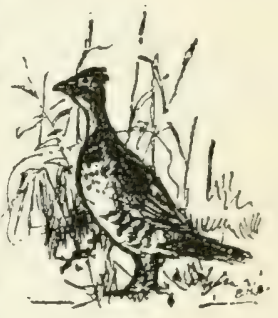
cessful woodcock shooting difficult, and the hunter must be a good snap-shot. The woodcock is unsurpassed as a table or game bird. The ruffled grouse is in the same class as the woodcock. No sound is dearer to a sportsman's ear than the drumming of a grouse as it drifts out on the quiet Indian summer air, across some sheltered valley. No sight thrills us more than a glimpse of the broadtailed, golden bird whirring away through the leafless alders. With what pleasure we look back on the days when, accompanied by some faithful dog, we hunted the coverts. 
The ruffled grouse, or "partridge," as he is often called, is a brave and hardy bird. Besides the danger from hunters, he withstands the hunger and cold of long winters with fortitude.

Buried underneath the snow, he hears the savage winter blizzards shrieking by, and when Nature's mood has softened, he breaks his way to the open air, and seeks his food. An old New England cock grouse is a dificult bird to bag. The methods followed in grouse hunting are similar to those used in quail or pheasant shooting. The requisites are, a good dog, and a knowledge of the habits of the game. The habits of grouse are practicaily the same wherever they are found; so from the Western States to New England, the same tactics will prove successful. Grouse are early feeders, and rarely come into the open except at dawn or dusk. Their food consists of larvæ, insects, and different kinds of grain. In winter, when hard pressed for food, I have found them in orchards, pecking the remains of the apple-crop; they also eat the tender buds of different trees.

Grouse like the sides of brush-covered hills; and the head of a brushy, well-watered ravine, is a favorite spot. In thick cover they are difficult to hit, and the hunter must be a good snap-shot to be successful. In fact, all upland shooting is quick shooting; the slow, methodical duck-hunter stands a poor chance in the uplands. On the Pacific slope, where the timber grows to a great height, 
the grouse lives a good deal in the trees. In little hunted localities, a covey will remain in a tree while the hunter shoots them, one by one, provided he shoots at the bird that is nearest to the ground; but they soon learn that a perch is no protection against firearms.

The most successful grouse hunters are the men who hunt the same localities every year. They learn the whereabouts of every covey, and know where to find them at any time in the day. Some grouse are domestic birds, and refuse to leave a certain locality, no matter how much they are persecuted.

This is a dangerous trait, as sooner or later they make a misiake and go home in the hunter's pocket.

\section{\$ \\ QUAIL}

Quail shooting in a well-stocked country is fascinating sport. As quail are usually found in bevies, there is more dash than in grouse shooting.

Quail, like the grouse, abound in the United States; and are even more plentiful, as there are some desert varieties that thrive in the Southwest, in country where grouse could not live. Along the Pacific coast there are several species of quail; the California valley, and mountain quail, the "Bob White" and a sub-species or two. 
The Bob White has been planted within the last few years, and seems to be doing well. The California valley quail is slightly smaller than the "Bob White;" it frequents the sides of rugged foothills and the heads of brushy canons.

The California birds, while furnishing fine sport for the lovers of dog and gun, do not lie as well as their Eastern brothers, and consequently, the man who makes a good bag must be sound of wind and limb.

I have seen an old dog who was well broken on "Bob White," completely lose his temper and self-respect, when hunting Western quail for the first time. After staunchly pointing several coveys that had "run out of the County" by the time we arrived, he attempted the tactics of the greyhound, and tried to run them down, much to the mortification of his doting owners.

Quail love farm lands. Any old wheat, oat, or barley field, with brushy edges, and brier-covered fences, is a favorite spot.

A good dog, and practice, will make any man an enthusiastic follower of this delightful sport.
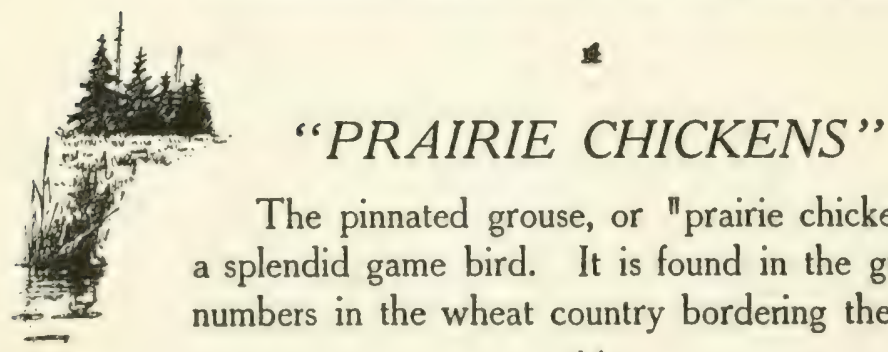

The pinnated grouse, or "prairie chicken," is a splendid game bird. It is found in the greatest numbers in the wheat country bordering the great 
plains. As the country is settled the prairie chickens increase in numbers, due to the improved food supply and added protection from their natural enemies.

As the prairie chicken is found in open country, wide-ranging dogs are used, and the hunters often

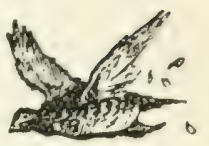
follow in a wagon. When the dogs "make game" the hunters alight, and the fun commences.

The prairie chicken is not a difficult bird to hit, as its flight is even. In fact, it flies in much the same manner as the meadow lark; beating the air with its wings, and "sailing" alternately. When the birds are fat they do not fly a great distance, and can be "marked down" easily, and followed. When unmolested they become quite tame, and can be approached by a man on foot, and killed with a rifle.

As the country changes, and wheat gives place to sage-brush, the prairie chickens are not so plentiful. The sage-brush, however, is the home of our largest grouse, commonly known as the "sage hen." The "sage hen" is not very good to eat, as they are found in the Western deserts, and their food consists largely of the tender tips of the sage-brush. This makes them taste sagey, and they are apt to be tough. A young sage hen is fair eating if it is drawn immediately after it is shot. As a game bird the sage hen is not a success, as it is not very plentiful. 
They are usually killed by the plainsmen who stumble on them while hunting or traveling.

As one moves towards the Western mountains, climbing up from the land of the sage-brush to the everlasting snow, you at last reach the hunter's paradise-the "park lands." The parks usually lie near timber line, and consist of beautiful glades and openings in the forest. This is the land of running water; of grand mountains, and game. Among the parks the hunter will find bear, wapati, black-tail deer, and the blue grouse. Blue grouse are rarely molested. In the mountains where they are found in great numbers, they are seldom molested, as big game is also plenty; the hunter desisting from grouse shooting lest he drive larger game from his neighborhood.

Along the Pacific coast grouse shooting is a favorite sport. This bird is larger than the ruffled grouse, and of a dark, blueish-gray color. A cock blue grouse that the writer killed in the Cascade Mountains, weighed five pounds.

The blue grouse is a tree loving bird, and spends most of its time during the winter in the tops of large trees. This probably accounts for its not growing a snow-shoe, like the ruffled grouse. It feeds early in the morning and at dusk. At sunrise it takes its bath in some sandy spot, where the sun strikes; and thic is the time to be afield. With a good dog, these morning tramps through the grassy glades, where the dogs show white against the dark hills, will never be forgotten. 
It seems incredible that in a country as well suited for wild game birds as ours, there should be any danger of their extermination.

With a few simple laws, well enforced, we would have an unlim-i ited amount of birds for years to come. But, outside of the selling of game, no laws should be needed. No man who is interested in birds can indulge in "Spring shooting." No man who has any self-respect, will load himself down with more birds than he can use, or sell game.

Now, if all of us refrained from selling game, from Spring shooting, and unnecessary slaughter, we would need no game laws. The game butcher is the enemy of all self-respecting sportsmen, and should be treated as such. There are two more enemies of our game birds that we are all familiar with; the cat and the trap. People who have never studied cats, or who orwn them, would not believe the damage that these animals are guilty of. The slaughter that they commit among our song birds is bad enough; but when they destroy our noble game birds, they are indeed a curse. I have tracked many a farm cat in winter, and the trail almost invariably ended in feathers and blood. Every hunter has surprised cats on good quail ground, far from any habitation. These cats are practically wild, and live largely on our song and game birds. 
There is only one way to treat cats and traps when they are in the woods, and that is to destroy them.

Traps for catching quail are often set by country boys who do not realize the damage they are doing. When they find a trap destroyed, it usually makes an impression on them and stops their wrong doing. Hardened offenders, however, need stronger methods; and it is every sportsman's duty to see that they are punished.

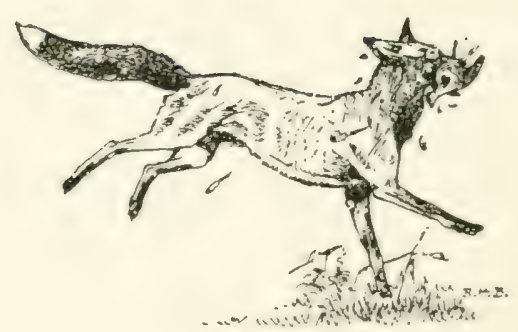





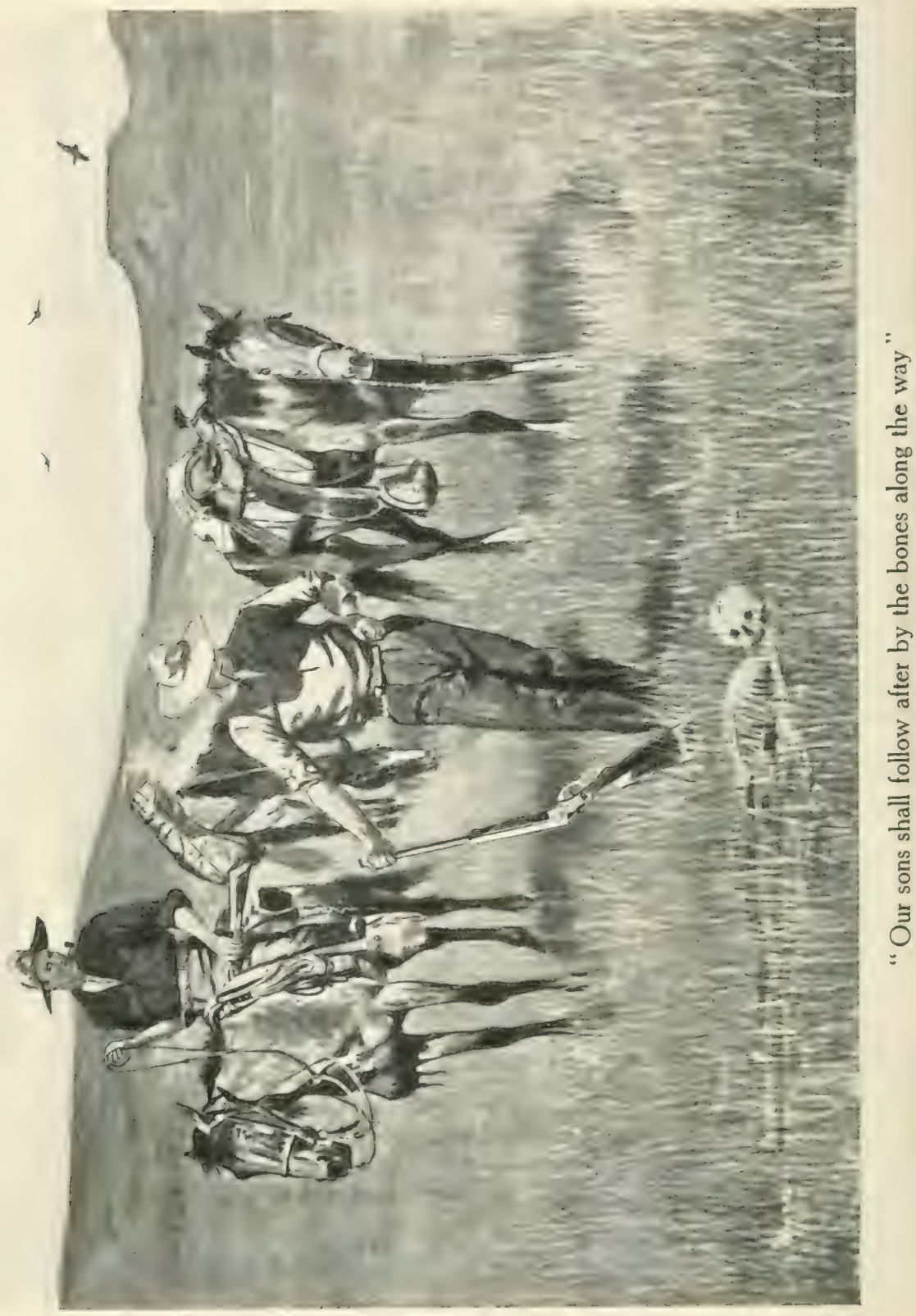




\section{CHAPTER VI \\ 5 \\ A Brief History of Firearms}

V THEN man first inhabited the earth, and wild animals were numerous, very rude methods of hunting proved successful. As time passed, and men increased, game was more difficult to approach and capture, and the need of a weapon that would kill at a distance, was felt. Then some pre-historic genius, from a strong staff and a piece of sinew, made the bow.

Others found that they could hurl rocks to a great distance by placing them in a shallow pouch at the end of two thongs; and thus they made the sling. But it was the discovery of gunpowder in the XIVth century, that sounded the knell of the spear and the bow, and made the deadly firearms of modern times possible.

But as it was with the bow, so it was with the gun. Game became more difficult to approach, and wars demanded improved weapons; until today we have guns that kill further than the eye can sight the mark, and that shoot with unnecessary rapidity.

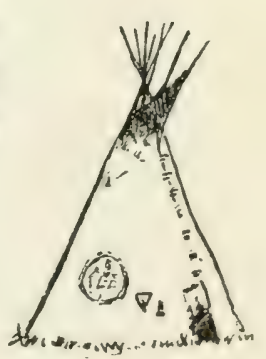


When we read the history of the Western Hemisphere, from the time when Columbus and his followers broke its long sleep with the roar of their match-lock, we cannot but notice what an important part firearms played in settling the great land. Imagine the stolid Dutch fighting the treacherous Iroquois with their own weapons; or the settler, unarmed, driving westward his plodding ox-team, when the great plains teemed with buffalo-hunting savages. Unjust as our dealings with the Indians may seem, the settling of that wilderness without powder and bloodshed, would have been a dificult maitter. Besides hating the whites for taking up their land, and slaughtering the buffalo herds, the red men, like the knights of old, looked on war as a pastime, and a means for gaining advancement and honor. The young "brave" was not a man until he had scalped an enemy killed in battle.

Since the war of 1812, Americans have won world-wide fame for their skill in the use of firearms. From the early wars, when our weatherworn frontiersmen drove back the English, and the Indians, our success has been the result of splendid marksmanship.

The gun that made our country what it is, that gave us our independence, and was the "open sesame" of the "dark and bloody ground," was the old long-barrelled muzzle-loader. This old gun was as much an American institution as the 
log schoolhouse and the "old oaken bucket;" and to this day, with the bullet-pouch and powder-horn, in remote communities, it still harigs in the place of honor, over the old fire-place.

This gun was a splendid arm, and with it the followers of Boone and Crockett began the advance that has since spanned the Pacific. Out-door sports were heartily encouraged by the early pioneers. Shooting competitions were very popular, and the cream of the frontier marksmen gathered at these times. The match was usually for some prize, and often remarkable skill was shown by the competitors.

The improvement in firearms went on slowly, and the introduction of the cap gun was the first important step towards the modern metallic cartridge.

But before we leave the old muzzle-loader, I should like to say a word concerning its efficiency. Even at the present time, there is no firearm better suited to a wilderness trip than the old percussioncap, muzzle-loader. Within reach of civilization, where ammunition can be secured easily, modern guns are, of course, far better and more trustworthy. But when a hunter is making a long trip through the wilderness, and is dependent for his meat on what he kills, there is no gun more useful than the muzzle-loader, because of the lightness of its ammunition, and the variety of charges that may be used. 
In the old days, when an Indian bought a gun from a trader, he would stack beaver skins around the arm until the pile was level with the muzzle. The gun then belonged to him, and the trader took the skins. But it is interesting to know that in these days of invention and science, the flint-lock has held its own ground; and that in the great country that lies along the Arctic ocean, roar of black powder still startles the caribou herds, and rumbles along the mountain sides.

After the Civil War, guns underwent another change. As we are all familiar with modern arms, it is not necessary to describe the different patterns. The modern gun has, however, given us two important points: that single-shot rifles are unsurpassed for accuracy, and that smokeless powder is superior to the black powder.

The story of the settling of the West is one long list of valorous deeds.

The frontiersmen and Indian fighters were a hard and unruly class of men; but this is true of every community where "might makes right," and where the only law is the survival of the fittest. Even the so-called "bad men " were often men who killed in self-defence, and who possessed many rude virtues.

These men were always armed. In serious work, in the open, they used the rifle, but for close quarters they preferred the pistol. The pistol is, 
of course, a short-range arm, but in the hands of an expert it is a dangerous weapon.

Some of the feats that the frontiersmen performed with the pistol were truly remarkable. As the life was free, and the country new, shooting scrapes were sure to result, and many a desperate fray was waged in the frontier cattle towns.

As a rule, these fights were between individuals. Sometimes, however, trouble arose between rival ranches, or towns, and then, indeed, the fighting was serious.

As the country became settled, men were appointed to enforce the laws. These sheriffs were chosen for their courage, indomitable will, and skill in the use of firearms. Sometimes they were men who had themselves made "records;" and some even were desperadoes, who, once reformed, did yeoman's service in suppressing their unruly henchmen. It can be easily understood that with horse thieves, hold-ups, cattle-wars, cowboys and buffalo-hunters to contend with, the lives of these peace-promoters were rather uncertain; particularly as their notoriety made them the butt of any drunken desperado who had confidence in his cwn skill with the pistol.

With the coming of railroads the Indians and game were driven back, and as the country was settled, enacted law took place of the gun and lariat. To-day

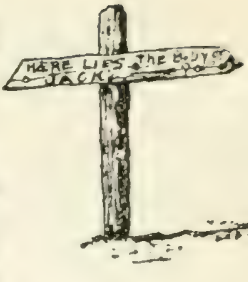


there is a growing interest in and appreciation of firearms.

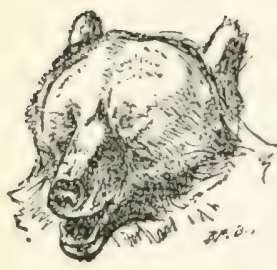

The strength of a nation depends on the strength of its people. One of the strongest reasons for our boys and young men becoming skillful in the use of firearms is, that at any time they may be called upon to protect their flag and homes. A man who will not fight for his country, if the need arise, is, of course, to be despised. But a man who knows nothing of firearms, is, for a time at least, almost as useless. To-day, an army of sharpshooters, even with conditions against them, have the best chance to win, as modern warfare is carried on at long range. The other advantages to be obtained by the use of firearms are physical.

There is probably no life more beneficial, physically, for a man, than the life of a hunter. Besides building up the muscles and sinews, it produces those traits of character necessary for success in life. Frontiersmen, the world over, are noted for their

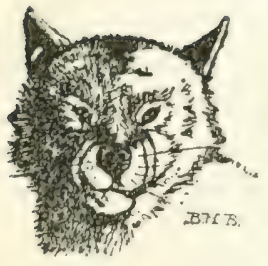
hardihood, courage, and resourcefulness.

Nature has been lavish in stocking our country with wild animals. Since the world began, man has been interested in the chase.

Originally, the desire to kill came from the necessity of procuring flesh and skins to sustain life. Now, it is handed down to us in the form of an instinct, which is accentuated by a longing to escape the frenzied life of our large cities, and enjoy the beauties of nature. The fascinations of a hunter's life 
are many, and particularly so to the man who has to spend a good part of his life in civilization.

Every year finds an increase in the number of men who go to the wilderness. Some merely spend their vacation "roughing it;" but there are a few who return to the wilds as to a magnet, fighting the faces of nature for the love of it, and penetrating into rough and unknown ranges. There are many reasons for this: the instinctive love of adventure that we are born with, and the desire for action and excitement.

The physical strength engendered by the chase, appeals strongly to some men; and the fickle goddess of fortune leads others through forest and valley in pursuit of the yellow metal.

But whatever your purpose is, be it the pursuit of gold or adventure, the rifle is your surest companion.

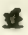 \\ MARKSMANSHIP}

Of course every one who handles firearms is ambitious to become a good shot. But marksmanship is a misleading word, and may have many different meanings. First, we have the marksman who devotes himself entirely to the target. Here is a man who has trained himself in a machine-like regularity. He knows from the flag where each bullet hits, and shoots his next shot accordingly. He shoots at known ranges continually, and knows 
a hair how to sight his gun for each distance. Each individual target is shot at from one position, and under the same conditions. This enables him to use a wind gauge. This practice is usually at certain times in the day, and therefore he is used to having the sun in a certain position. And lastly, he shoots at a brilliant mark, and can take his time.

The hunter's marksmanship is totally different. Instead of having things arranged for his comfort, he almost invariably has conditions against him.

The sun may be in his eyes, or the gloom of storm or forest may blur the sight. The savage mountain winds will blow his front sight half an inch from the mark, and the cutting sleet will drive into his face. He must judge every distance under very difficult conditions, and a miss is a lost shot, as he can seldom tell where it struck. A wind gauge is useless, as he is constantly changing his position; and his hand is often shaky from physical exertion. And to make matters worse, his mark has a protective color; is seldom motionless, and hardly two shots are ever fred at the same range. The result is that hunters, as a rule, use the simplest sights, and shoot quicker than for target shots.

It is a matter of knowledge that good target shots are frequently poor shots in the field. This is due to the fact that the target shot is unused to 


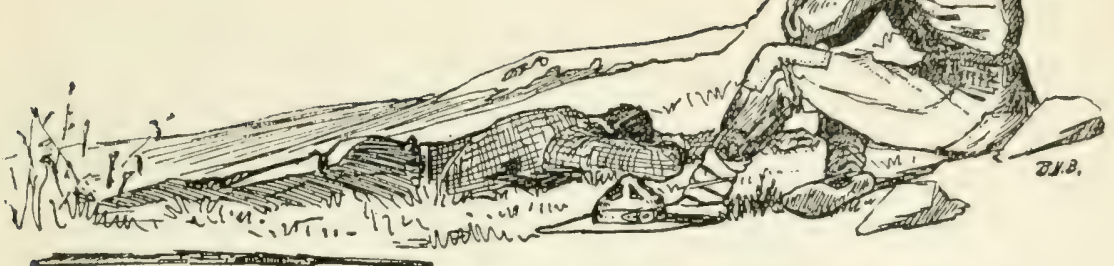

adverse conditions, or rapidly moving ranges, and is in the habit of taking his time.

I have repeatedly seen game killed by field shots, by snap shooting, where target shots were helpless. My first experience with a really expert field shot was in Southern Alaska, and is a good example of the skill that can be developed in off-hand shooting. As we were crossing a small glade, a spike-buck jumped from his bed on the edge of the timber. He was about a hundred yards away, and was out of sight in an instant.

My companion took a snapshot at him, and, as I thought, missed. On reaching him, to my surprise, he said: "I pulled on his shoulder, but held a little too high; he'll drop, though, inside of two hundred yards."

It was as he said. The shot was fair in the shoulder, but about six inches high.

Of course what is true of target shots in the field, is also true of field shots at targets. Target shooting is excellent practice for the beginner, but tends to make him stale if carried to excess. The boy who is learning to shoot should familiarize himself with all sorts of targets under all conditions. If he is 
gifted, and shoots infrequently, he will be what is far better than an expert in one branch of shooting"a good all-around shot." Even among one class of marksmen you often find a marked individuality. Famous shots are not made; they are born. Yet it is possible for any man to become a good marksman.

The sooner one begins, however, the easier it is to learn to shoot, and to absorb the principles that render accidents impossible. It is well known that the majority of "gun accidents" are caused by men who are inexperienced.

The Boers of South Africa are an example of men who have developed into splendid marksmen from constant shooting in the open.

One of the most important factors in good shooting is a clean gun. This fact should be drilled into one in early youth, as it then becomes second nature. Cleaning guns, particularly in the field when one is tired and sleepy from the day's sport, is often a nuisance. The time to clean a gun is immediately after using it. It is easily cleaned, then, and the longer you wait the more difficult the task is. There are many cleaning oils made, and all are fairly satisfactory; but the best gun-cleaning ingredient yet discovered, is "elbow-grease."

It is always appropriate to end a yarn about guns by a warning against carelessness. 
Care in handling firearms should be taught every boy as soon as he is old enough to raise a gun to his shoulder. How to hold a gun, extract shells, get over a fence, take a gun from a boat, and clean a gun - all this, and much more, he should know.

Hunting in the open is a more serious proposition. The ease with which a man can make terrible mistakes in the field, is terrifying. In country near civilization, even an experienced man must use the greatest caution, lest he mistake a human being for game.

A true story, told me by the chief actor in what nearly proved to be a tragedy, shows how liable we all are to this mistake. Two experienced hunters left camp early one morning to hunt deer. One went to due south, the other to due north. The one who went south, immediately found a fresh buck's track, which led him in a large circle to the north. When about four miles to the north of the camp, he found he had lost his knife, and backtracked to the place where he thought he had dropped it. The place was a small thicket, and he got on his hands and knees, and followed his trail, looking for the knife in the soft snow. The hunter who had gone north, originally, travelled very slowly. At last he topped a small ridge and

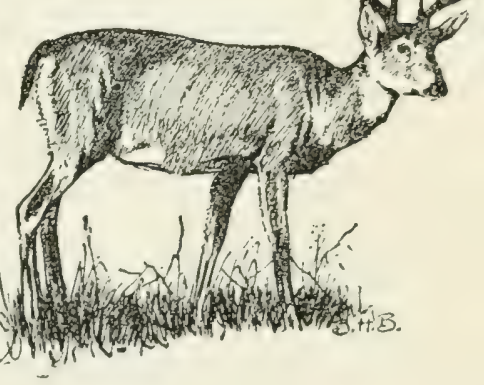


looked over. In a patch of brush a hundred yards away, he saw a brown object, shaped like a deer, moving slowly through the brush. Further on he saw fresh tracks, and his hunter's knowledge told him that the brown object was a young buck tracking a small band of his own kind. The hunter was a splendid marksman, and drew a bead on the deer's head, and was about to press the trigger, when something about the deer's movements made him stop. At the moment the deer stood up. It was his friend, and he had just found his krife.

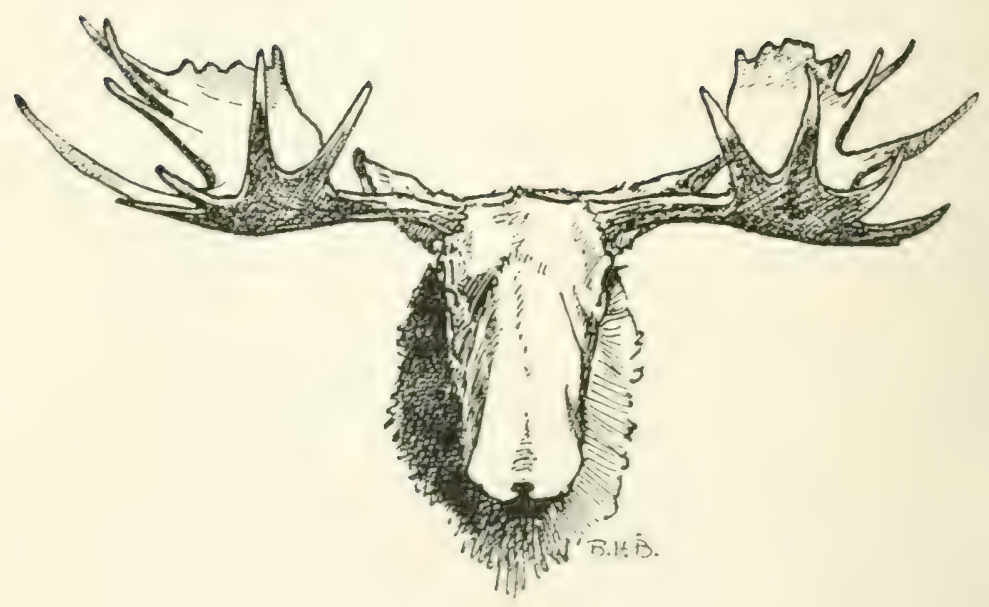





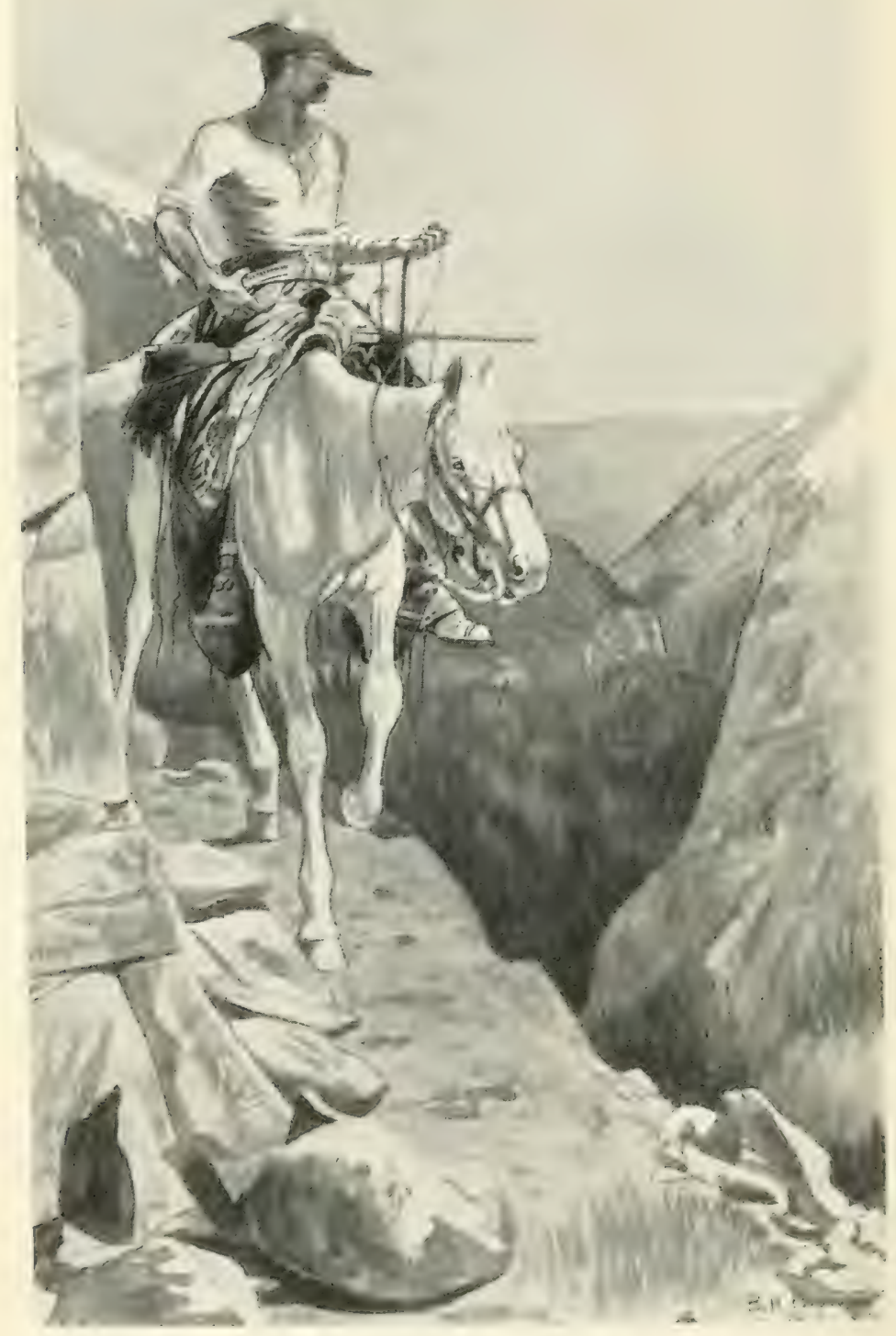

The Wilderness Hunter 


\section{CHAPTER VII \\ 起 \\ The Wilderness}

7 TE trail is the one human artery that beats in the wilderness.

As the life of a man is in the wilderness, so is the trail. All the human sufferings, hardships, and dangers, sought and mastered by the advance guard of civilization - the trail builders - are reflected in every tortuous curve of the dim path. As the hunter with the call of the wilderness in his ear, pushes beyond civilization into the wild land, and beyond again into the unknown, the trail writes down in living letters the story of his joys and sorrows.

Take twenty experienced frontiersmen, and send them one at a time through an untrammelled wilderness to a given point, and on comparing the trails, we would find that the majority had followed practically the same route. This route is always the line of least resistance, and in following it we take the wild animals as teachers. When big game animals first enter a country - and they are always changing their feedinggrounds - they do not know their surroundings, and consequently travel to and fro by 
instinct. Their movements are also affected by the character of the country, and they follow the easiest natural route to their destination. In time they beat down trails and discover the safest fords, until their system of roads is complete.

Then come the hunter and prospector. They do not know the country, and use the trails the wild animals have made. With the rattle' of firearms comes the "tank-a-tink" of the pack-train bell, and the trails are widened and flattened by the hoofs of mules and horses. As the country becomes settled the trail changes to a road; and at last, where once the moose and wapiti called and bugled, nature's music is drowned by the scream of the locomotive.

This all goes to show that trails are not made in a night and that the man who can pick out the best road through an unexplored country must have a liberal wildemess education.

\section{\&}

WOOD AND In wilderness travel, three things WATER are absolutcly necessary to ensure success and comfort,- - wood, water, and feed. By feed, I mean grass for the horses. Pack animals are used so often in this work, and so much depends on their ability to travel, that all comfort should be sacrificed, if necessary, to ensure their getting good food. The experienced hunter or explorer thinks first of his pack animals, 
and lastly of himself. Howcver,good camping places can usually be found, and add largely to the pleasures of wilderness life.

\section{\$}

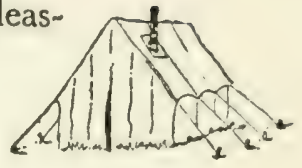

NEATNESS AND The hardships of wilderness ORDER travel are many, and what smal physical comfort is enjoyed is gained by the sweat of the brow. For this reason, an orderly camp is a long step towards comfort. It is not personal neatness that counts, however, but the arrangement of your camp. Every detail should be carried out systematically, from the unpacking of your horses to the arrangement of your beds for the night. I have been in camp with men whose personal neatness was a hindrance as they would keep a whole pack train waiting while they roped up a small pack. These same men would unblushingly leave all the pack harness scattered about, and the dishes unwashed.

After seeing that the horses are comfortable is the time for arranging camp. As some put up the tent or fly, others prepare the evening meal. As

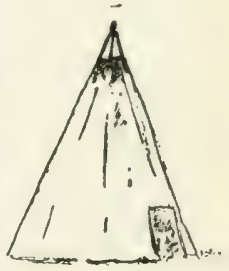
long as there is anything to do in camp, keep busy, and when at last darkness comes, and the pipes glow around the camp fire, your happiness is complete.

Camp making changes little from day to day, and by making camp in an orderly way, you will save time, hard work, and worry. 


\section{TENTS}

On long trips your tent is the only protection you have from the elements. From north to south men are living in these light shelters, suffering alike the blizzards of the north, and the heat of tropic lands. As can be imagined, a shelter that has so many requirements must be built on many different patterns. But when all is said, the best-known type to-day is the common wall or A tent.

This tent is easy to put up, and is comfortable, and can be packed into a fairly small space. There are several varieties of the wall tent, all of which are satisfactory, and any tent purchased from a good outfitter, will serve its purpose.

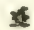

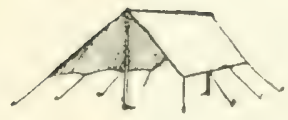

FLIES

The fly is the ideal shelter of the wilderness hunter, and where a man must travel light, and at times carry his own duffel, it is without an equal. A fly properly slung gives almost as much shelter as a tent, and to my mind is more cheerful, as one is not completely shut in, and can see the beauties of nature about him. With tents, one uses a small stove, but with a fly, the camp fire is more useful.

There are mary ways of putting up a fly, and the experienced woodsman will see at a glance which one of the many suits best the camping place he has chosen. As a rule, it is slung with the highest part toward the fire, and sloping down 
toward the back in the shape

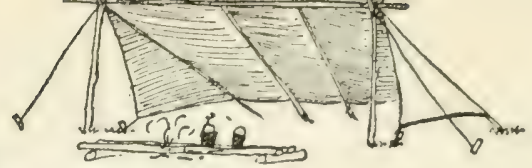
of a reflector. I have spent months in the wilderness with nothing but a fly for shelter; and to my mind no time is pleasanter than the evening hours, when, talking with your companions, you lie back on the bough beds and watch the sparks from the balsam fire drift off into the night.

The fly is only useful where wood is abundant, and in sparsely wooded country, such as the Behring Sea coast, a tent and stove are necessary. The fly takes up very little space, and can be rolled up to suit any pack.

Men in the wilderness have used flies successfully in making boats when caught without food, or crossing rivers in flood time.

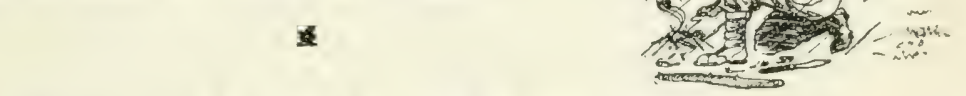

FIRES A poor fire, made from punky, damp wood carelessly thrown

together, is, besides being a strain on the temper, a source of possible serious trouble. A fire made like a pile of jackstraws is apt to collapse at any minute, and precipitate pots, pans, and food into the flames. Besides, it is a waste of wood.

The first things needed in the making of a good fire are fire-dogs. To have your wood burn clearly and evenly, and give out the greatest amount of heat, you must have it raised from the ground. Fire-dogs made of rocks, or pieces of green wood, are easily obtained, and simplify camp cooking. 


\section{STOVES}

There are several kinds of stoves made for camping, and they all serve their purpose.

They are practically the same, only differing slightly in construction. The features necessary are strength and compactness. The stove-pipe should be in short lengths, telescope, and fit in the oven. There stould be no legs, or any protruding parts of any kind, as they would be broken in transportation. Almost all camp stoves heat up to an extent that makes baking bread difficult. This feature may be overcome by placing pebbies on the floor of the oven and cooking the bread with the door of the oven slightly open. Some stoves are made with the oven separate. The oven, in this case, fits on the stove-pipe, but it is inferior to an oven in the body of the stove.

Before making a fire in a camp stove, it is always a good plan to fill the fire-box with an inch or two of sand. This protects the sheet iron and makes it last longer.

\section{5}

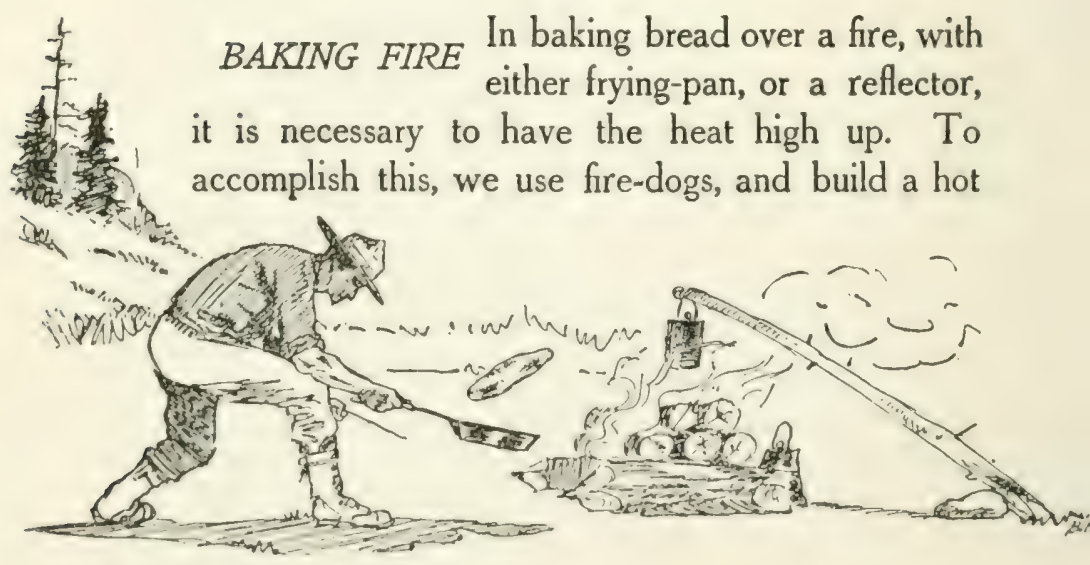


fire. A log laid on the ground back of the fire, converts it into an oven, and the heat strikes directly on the bread. Baking-powder bread should bake quickly, and a hot fire is necessary. The mixing of baking-powder bread is given on the outside of the baking-powder cans, so we will not go into detail. All is not in the mixing, however, and a few simple rules, if followed, will prove useful. As bacon is of great value in the wilderness, we will naturally economize as much as possible in its use. Usually the frying-pans are greased with bacon, to keep the bread from sticking; but this is unnecessary.

After cleaning the frying-pan, powder the bottom evenly with dry flour; place the bannock or loaf, in the pan, and flatten it out. A hole made in the middle of the loaf, will render it less liable to stick. Hold the frying-pan over the fire long enough to let the loaf harden on the bottom.

This will keep the bannock or loaf from turning over when the pan is tilted on edge. While heating the pan, you should shake the bannock, occasionally, to loosen it from the pan. After the bottom of the loaf is sufficiently stiff, tilt the pan up in front of the fire by resting it against a log, or pushing a sharpened stick into the ground, and resting the ring in the frying-pan handle on the end of the stick.

Bread made in this way will not be as brown as bread that is made in bacon fat, but it goes just as far. 
The only things necessary in a FRYING FIRES

frying fire are stability and flatness. A great deal of heat is not needed, and it makes the cook uncomfortable.

For this reason, two good logs, laid side by side, with a bed of hot coals between, answer every want, and give lots of room.

\section{*}

ROASTING Roasting is a very useful method FIRES of cooking. In the wilderness, men often fry all the meat they eat. This necessitates eating a large amount of grease, and is apt to bring on indigestion. Besides, cold fried meat is decidedly inferior to cold roast meat, and it does not keep as well. Roast meat, or "scotacook" as the Northwestern Indians call it, is easily made. The fire should be high, and built in a circular form, so as to throw heat from almost every side. Then take a strong string that has been thoroughly soaked in water, and tie one end of it securely to the meat, and the other to a pole from which it is suspended over the fire. The meat would burn if left alone, but the cook winds the string up by turning the meat around. When the meat is loosened, it will wind and unwind many times, from its own weight, and cook well and evenly. Small pieces of meat may be easily roasted by spitting them on sticks sharpened at both ends, and stuck up in front of the blaze.

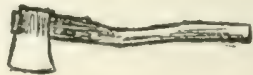




\section{BOILING}

Boiled food is, like roast meat, a welcome and necessary change from the frying-pan. A good stew, made from the rich meat and bones of a big game animal, is food that will carry a man many weary miles. Adding a little rice, or a few dumplings, and "raisins, gives the stew a better taste. In boiling anything it is better to have the pot suspended, either from a pole resting in two crutches, or a single stick is stuck in the ground. This keeps the heat on the bottom of the pot, where it belongs.

Plenty of water, and watchfulness, are required, as a stew is apt to go dry, and burn, or boil over, and lose its richness.

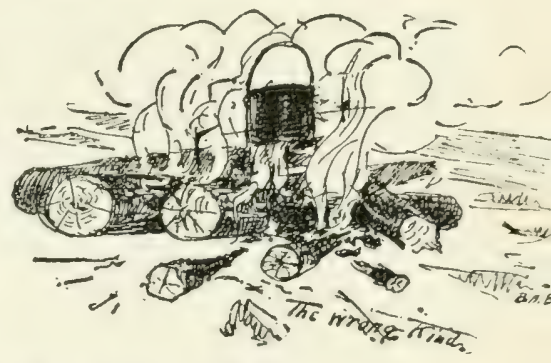

COOKING All that you really need in the

UTENSILS way of cooking utensils for a camping trip, are pots and frying-pans. What yuu do take will depend on the size of your pack-train, the roughness of the country, and your own ideas on the subject. The best, in wilderness work, however, is almost always the simplest; and if you leave your heavy Dutch ovens, iron pot, etc., behind, the chances are that you will not be sorry. As usual, you should economize in space. All your pots, pans, cups, and frying-pans, should nest. This makes them less liable to bend or break, and they 
are more easily packed. It is well to have five pots in a nest, and your cups, knives, forks, and spoons fit inside of the smallest pot. The plates fit snugly on top of the complete nest. This is a very compact outfit, and is a great time and trouble saver in camp. Tin lined copper pots are about the best, as they are less liable to rust.

It is a good habit to use each pot for a certain food, as it saves time and confusion. The smallest pot is usually the right size for boiled fruit. No. 2, is your tea or coffee pot. No. 3, is for beans; and No. 4, is used for stews on account of the size of the bones. No. 5 is used for clean water, and kept near the fire. It is much better not to use this pot for cooking, as it forms the outside of the nest, and if used on the fire would blacken everything it touched.

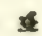

CAMP COOKING $\begin{aligned} & \text { The greatest difficulty in camp } \\ & \text { cooking is solved by a good }\end{aligned}$ supply of firewood.

It is useless to begin bread baking, or roasting with a poor lot of fuel. After a good fire is started, is the time to begin cooking your food.

The next difficulty is to calculate the time it will take for your different foods to cook, and to have them ready for the table at the same time.

Lastly, the camp cook should work rapidly, as there is not much time left for cooking in a day's

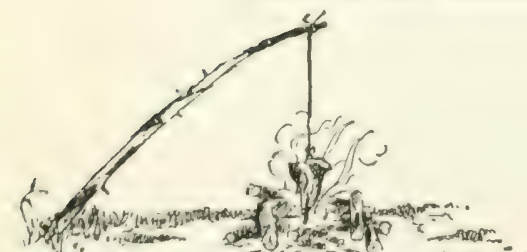


travel in the wilderness. The cook should be able to start a fire, boil tea, make or heat bread, and fry meat, while the rest of the party are bringing in the horses and breaking camp. After breakfast, he must wash the dishes, pack up the kitchen box, and prepare the cold lunch, while the others are packing the horses. The last horse packed, and the first horse unpacked, is always the animal that carries the kitchen outfit. The cook should keep an eye on the food supply, and decide on the amount of food to be eaten.

A little economy will often make food last a long time, where with careless management the party would have to go without. If game is plentiful, the cook should stop using bacon, so that when the fresh meat gives out, the supply of bacon will be undiminished. For the reason that wild meat cooked with bacon is very palatable, a thoughtless man will often cook both together, thereby burning his candle at both ends.

Baking-powder bread, when eaten for a long time, is not wholesome. As it does not rise as easily in the open air as in a warm kitchen, some cooks attempt to make it light by putting in a great quantity of baking-powder. This is, of course, wasteful, and makes an indigestible mess. In fact, it is only by constant watchfulness and economy, that the wilderness food supply is made to last.

As to the actual cooking of food, any one can learn, who has patience. The simplest methods are
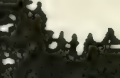
used; boiling, baking, frying, and roasting being done over the open fire. Of course I am speaking of the rough life in the wilderness, and for men who are energetic enough to do their own work. There are so-called "camps" where people congregate and enjoy the !uxuries of feather beds, modern plumbing, and lobster à la Newburg. But to these men the very thought of cooking their own food, or carrying a pack, would be decidedly unpleasant. Indians, in the far Northwest, have a way of cooking a moose head that they relish greatly; and the same way of cooking can be used effectively in camp for fish, game, etc.

After cutting the head from the moose, they plaster it with clay, and cover it with hot coals and ashes. This bakes the head very slowly, and leaves the meat juicy and tender.

While I have not cooked a moose's head in this way, I have more than once cooked fish, ptarmigan, and grouse, and the method certainly imparts a delightful flavor to the food.

Hunters often through thoughtlessness throw away delicacies that are even rare in civilization. The best parts of large game animals, such as the brains, kidneys, heart, liver, and tongue, are often passed by. Moose-tongue boiled, is one of the finest foods a man can have. It is tender, easy to carry, nutritious, and delicious when cold; and yet I know many men who have killed moose, and never thought of eating tongue. 
The brains of a moose, sheep, caribou, and in fact of all big animals, are extremely good to eat; and yet they are usually thrown away after the sportsman has gone to the trouble of packing the head into camp. There are men living to-day who have shortened their lives, and suffered the terrors of starvation in the wilderness, when, had they practiced iron-bound economy, they would have had food to spare.

\section{GRUB}

The grab proposition depends upon your own taste, and the facilities at hand for packing. Flour, beans, tea, sugar, salt, and bacon, are necessities. Anything else depends on how much you can carry.

\section{4 \\ BEDS \\ Bedding suitable for the "bush" can be secured at any outfitting} store or wilderness post. In very cold weatherfrom 10 degrees below zero, down-a sleeping bag is of course the best kind of bed. The sleepingbag habit is, however carried to excess.

Many men will load down an outfit with cumbersome bags, when two light blankets would be ample for warmth. And in really serious work, the horse blankets from the pack animals are plenty good enough.
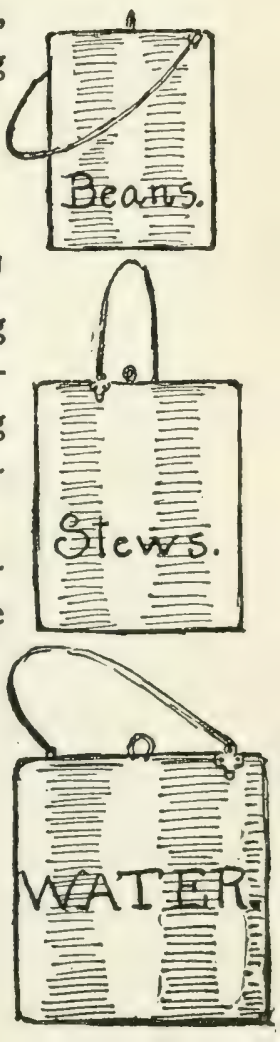
PACKING A knowledge of packing is one
of the most useful gifts a man living in unexplored lands can have. Some men never learn how to pack. The science of packing is really based on the ability to bundle up a mass of duffel neatly, and into the smallest possible space. In traveling with horses, preparing the loads is complicated by the fact that most of the packs must weigh evenly. That is, every sidepack must have a mate, or the load will not ride well on the backs of the horses. This necessitates good judgment and experience on the part of the man who first arranges the outfit for the trail.

The pack-train once under way, the packs are kept separate, and the worry is to a great extent done away with. Of course certain packs grow lighter from day to day, such as those that contain food. This makes overhauling of all the loads necessary from time to time. As enough could be written about packing to easily fill a good-sized book, it is impossible here to go into any detail. But if the beginner starts out with the idea that packing is an art, and that it cannot be done too well, he has made a long stride toward success. As wilderness work is done as quickly as possible, packing is reduced to a system; and when the packs are unloaded at the end of the day, they must be arranged immediately into such shape that repacking them can be done easily and quickly. 
In wilderness work there are three ways of packing-horse, dog, and man packing.

\section{\&}

PACKING Before the novice begins his first HORSES trip with a pack train, he should make himself familiar with one or two variations of the hitch. This is absolutely necessary. Next, he should make himself familiar with pack-saddles, and their uses, and learn how to "rope-up" packs. All this knowledge can be found in books. The hitches he can practice at home, and in a short time he will think himself capable of packing any animal that lives.

Then comes the momentous day when the train is driven in to the little frontier town, and cur tenderfoot, with some "old-timer" to help him, begins to put his "book-larnin' " to practical use. The result is a disappointment so keen that he remembers it with shame for many years.

In the first place, the remarks of the loungers who have turned out of the frontier bar-rooms to see the sport, are distinctly audible. An old, grizzled hunter turns to his companions, and says; - "Durned if he aint tyin' a bow-knot"—etc., etc.

The final outcome is that our novice begins all over again; but if he perseveres, the time comes at last when his "book-larnin" " proves of use.

The difficulty is that from Mexico to the Yukon men are packing horses, and it is very seldom that 
you find a number of men together who pack in exactly the same way.

Learn your hitch well ; test it in all kinds of hard work ; and you can smile when the other fellows talk.

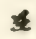

PACKING DOGS There are many stretches of country that are so rugged that penetrating them with horses is impossible.

The Selkirk Mountains, in the "big bend" of the Columbia River, are a good example. Dogs, for this kind of work, are unsurpassed. A good strong dog will cariy twenty pounds without diffculty. Take four dogs with you, and they can transport a little over one hundred pounds of grubenough for a long time-while you carry your own pack.

In summer work of this kind, the dogs will practically feed themselves, and as all the wild country of our Northwest teems either with big game, or animals of the marmot family, it is not a difficult matter to get meat. Salmon is also a favorite dog food, and can be found in all the water systems that flow to the Pacific Ocean.

I have used dogs in some of the ruggedest country in Northern British Columbia, and found them to be good weight-carriers.

All the harness necessary is a canvas saddle, built in the shape of two large pockets. After the 
pockets are filled, the saddle is placed on the dog's back, and tied on with a rope that goes around the pack and across the dog's chest.

\section{4}

\section{MAN PACKING}

When a man is traveling through an unknown country with a heavy pack, he is doing to my mind, by far the hardest labor yet devised.

When a Western man speaks of packing, he does not necessarily mean packing as it is known along the Atlantic Coast, or Canada.

This packing is usually done on portages, and even a man who is not very strong can carry his hurdred pounds a mile or more. In the far Northwest, and Alaska, however, there is not much canoeing, and men go far into the wilderness with all their possessions on their backs. In this sort of work, Western men not only carry what would amount to a good portage load all day, but keep at it day in and day out, for long periods.

Of course I do not mean that Canadians or Eastern frontiersmen are unable to do the same work; but due to Canada's splendid facilities for canoeing, the need for long-distance packing seldom arises.

Now among frontiersmen there is an expression that perfectly describes the tender-foot's first attempt at carrying a load. The expression is "fighting a 
pack." The novice when he starts into the wilderness with a heavy load, begins by thinking that it is easy work. He goes up hill quickly, wastes steps and strength, by stepping on logs instead of over them, and at the end of his first two miles is played out. His pack has, like a trained prize. fighter, banged him over the kidneys until his legs wabble. He is afraid he is going to be left behind, that the skin is coming away from his shoulders, and that he is going to die. In other words, he has been "fighting his pack."

I will not go into detail and describe pack shapes, as I have used every kind, from the wooden Russian alints shape of Behring Sea, to the "tump-link" of Canada, and they are all equally uncomfortable. The things to learn in packing are these-Arrange your pack as well as you possibly can; think of something pleasant ; rest regularly, but not too often, and DON'T worry at your load.

Once I was packing a good load across the Alaska Peninsula to Behring Sea. The sun was hot, the snow was deep and soft, and my feet had chafed in my heavy rubber boots. I was "fighting my pack" and getting beaten. How it started I don't know, but I began thinking of a pleasure trip I had taken years before. When I "came to," I found that I had carried my pack over a mile of the worst part of the trail, and had not thought of it once! That was my lesson; and since then my back no longer "aches at the thought of a pack." 
FORDING A stream in the STREAMS wilderness may be either a blessing or a death-

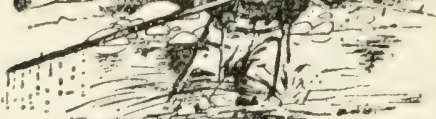
trap. When the hunter or prospector is traveling by canoe, every stream is a benefit, and the rushing waters carve for him a broad highway through mountains and lowlands. In many places, however, the streams are not navigable and the reason that makes them difficult to canoe- their swiftnessmakes them a source of danger to the hunter and prospector.

These men, in their wanderings, must continually ford them; and in this work they are often threatened with starvation, through the loss of their provisions, or with death, by the fury of the waters.

Ordinarily, there are only two ways of crossing a stream; wading and swimming. Swimming, of course, in a rocky, glacial stream, is not fun: so we come down to wading; and there are two kinds.

\section{s.}

PACK FORDING $\begin{aligned} & \text { Suppose tine stream is thirty yards } \\ & \text { wide, and you find a place where }\end{aligned}$ it is swift, but not over waist deep; here your grub will help; for an eighty-pound pack will hold you to the bottom, when without it you would be swept away. This fact is well known, and rocks or gravel from the bank will help, if your pack is too light to keep you down.

In this fording your pack must be well up on 
your shoulders, and ready to drop instantly; for if you fall down with a tightly tied or strapped pack, you will not come up until you have lost all interest in the undertaking.

\section{POLE FORDING If there are three or four in the party, decide on the best ford,} usually the widest stretch. Cut a slender pole, between eight and twelve feet long, and at least two and a half inches in diameter at the small end. You can always find balsams or alders on almost any glacier stream, except in high altitudes, and there the streams are small and the fording easy.

It is a good plan to take off your trousers, as there will be less resistance to the water; but keep on your footgear or the round glacial boulders will grind your ankles. When all are ready, stand in a line and grasp the pole. The lightest man (A) should be on the up stream, and the heaviest man (B) on the down-stream end of the pole. A's pack and clothes should be distributed among the others, as they need weight, and A will be under water occasionally.

Now all start across in line, walking down stream, always keeping the pole parallel with the current. As the water deepens, A may be swept from his feet, but he must hold on to the pole, for he is making an eddy for the others to walk in.

If possible, always pass below rocks. The 100 
water is deeper there, but less swift than on the upstream side. The first time I saw this ford made, was in Northern British Columbia, where three of us crossed a dangerous stream with perfect ease.

But in all fords, remember that it is the fool who never turns back. If the water feels too strong, return while you can, for a glacier stream knows no mercy.

\section{WOODCRAFT It is seldom that you meet a man really gifted in woodcraft. The} man who can call himself a good "all 'round" wilderness man, must combine much unusual knowledge. He must be a good hunter, which combines not only the ability to shoot straight, but also a keen insight into the lives and habits of wilderness arimals. Indians are almost invariably deficient in marksmanship, but make up for it by a good know!edge of the habits of wild game. White hunters are usually skillful in the use of firearms, but lack the patience shown by the best Indian hunters in stalking big game.

The woodsman must also be a good packer, a skilled boatman, a carpenter, a good cook, a pastmaster in the art of making shelters, and a man who is developed highly in that rare gift-resourcefulness.

Probably the wilderness hunters of the "buffalo days" came nearer combining all these qualities than any other type ever produced in America, as 
in their case the fundamental principles of woodcraft were instilled into them when children. But while the modern hunter may not be able to acquire all of the skill of the old-time trapper, he can by perseverance and hard work, become a man strong, self-reliant, reading the beautiful truths of nature as an open book, and fearlessly facing her anger. But while nature is a hard mistress, she has no rivals; once thoroughly in her power, the desires for wealth and social precedence are forgotten; and the breath of the woods, and the deep, bass song of the mountain, hold no secrets from you.

HUNTING

Every man who travels in wild countries, must at times go for long intervals without seeing any other human beings except those that compose his own party.

This makes the wild life about him doubly interesting, whether his object is the hunting of big game or not. If the lack of food makes hunting a necessity, then, indeed, the chase becomes a passion; and given a fresh trail, the hunter will travel on, suffering cold, hunger, and fatigue, until he meets with success or failure. Hunting big game successfully requires all the characterisiics that go to make a man successful in any branch of life. Determination, cheerfulness, optimism, physical strength, and good judgment, are needed, besides a knowledge of the habits of big game. 
STILL One of the most important facHUNTING tors in still-hunting, is, as the name of the sport implies, being quiet. This is a thing that the city-bred man finds most difficult; and he will actually insist that his progress is noiseless, when he is giving a good imitation of a "bull in a china shop."

Wild animals do not move rapidly; and if the novice will take them as a model, he will learn with surprise what real silence means. Go off into the woods, a mile or more from camp, and lie down. At first you are not conscious of any feeling in particular; but in half an hour the silence begins to sink into you. A crow caws far off in the forest, and at last you begin to realize what silence is. The sound of singing comes from the distant camp, and you wonder why Bill persists in making so much noise. A slender twig, two hundred yards away, breaks with a noise like a toy pistol.

The next time you go still-hunting, you travel one foot where before you moved twenty, and see game where before you only saw tracks, and fresh beds.

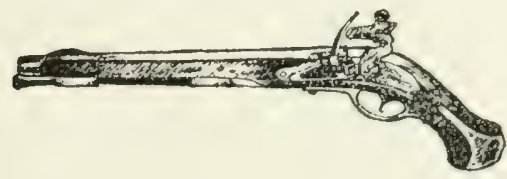




\section{Carelessness with Firearms}

One of the reasons that firearms are of use is that they are dangerous.

Of course we all know that the gun lover is 1 always a man who spends as much time as he can in the "open."

We know that hunting is a sport that builds character, makes strong muscles, red blood, and instills in us a love of nature. But with his first gun the boy begins the transformation that ends in manhood. For the first time his parents show confidence in him, and knowingly allow him the use of a man's weapon.

Now, to me, one of the most powerful reasons for training boys in the use of firearms at an early age, is, that most of the accidental slaughter committed with firearms is due to men who have not been given an opportunity to use guns in their youth. I am not going to argue, here, on the "didn't know it was loaded" man. He, as a rule, only hurts himself; and a little early training will soon instill into boys a fear of every gun. To me, the greatest crime committed with firearms is the shooting of a fellow human being in mistake for game. Any man who has ever committed this fault, no matter what 
the result may have been, should be forbidden by the laws of the country to ever shoulder a gun again. The crime is responsible to two things - senseless excitement, and criminal thoughtlessness or carelessness, and a man liable to either of these faults, is a menace in the "bush," or anywhere.

Let your bearing towards your gun be one of constant watchfulness. Let your enjoyment of hunting lie in the p? easure of studying the habits of wild animals, and in doing well a man's part in the dangers and hardships of the wilderness hunt. Let your desire be to kill what game you do, as a man, rather than to kill a lot, as a butcher. In this way you will grow younger as you grow old; and the freshness of the fields, the dignity of the mountains, and the laughter of the clear streams, will enter into and be a part of you.

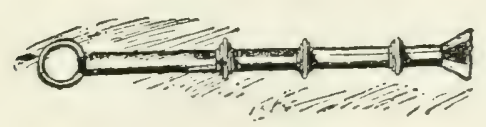

FINIS 


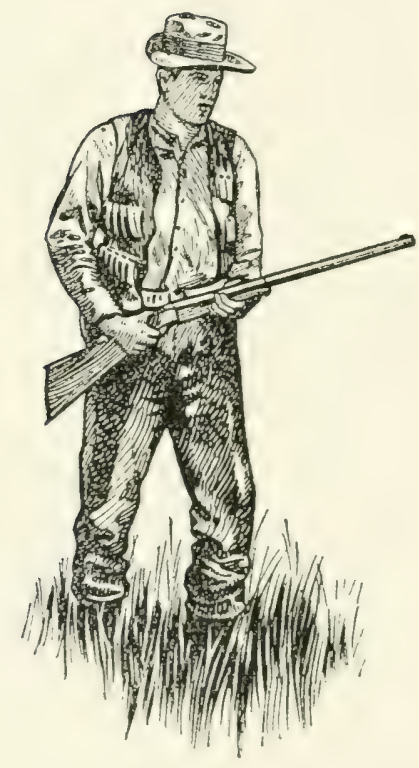




\section{STEVENS REPEATING \\ GALLERY RIFLE No. 80}

"THE BULL'S-EYE KIND"

Made to take the famous .25 Stevens R. F. cartridge. The only .25 caliber Rim-Fire Repeating Rifle on the market.

Stevens Repeaters are the most accurate and hardest shooting rifles in their class.

If you cannot obtain from your Dealer, we ship direct, express prepaid, upon receipt of Catalog Price.

Always insist on STEVENS when ordering.

Send 5 cents in stamps for 160-Page lllustrated and Descriptive Catalog. Replete with

STEVENS and general fire-

arm information.

J. STEVENS ARMS \& TOOL COMPANY

CHICOPEE FALLS, MASS. 


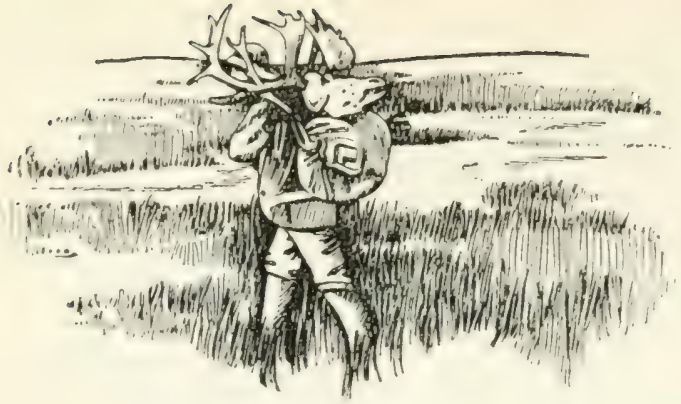

When camping, it is at times imperative to put up with a whole lot. Don't put up with a firearm of doubtful efficiency.

\section{Get a STEVENS!}

You will wonder why YOU missed doing so before.

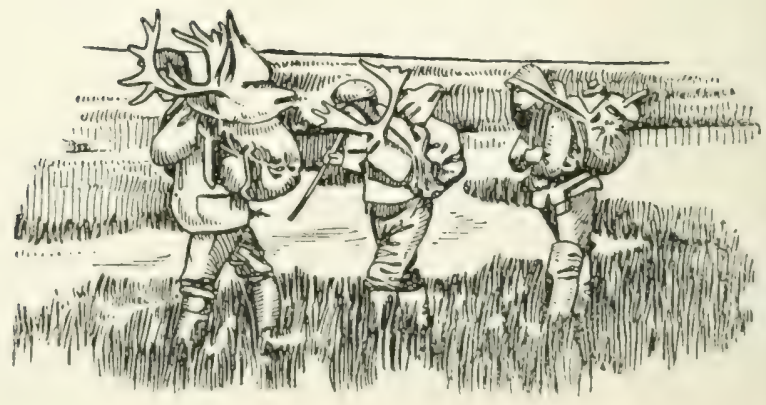


T V TE think that possibly a few words regarding our business may not be out of place, and might be of interest to the readers of "Cuns and Gunning." This Company began the manufacture of FIREARMS in 1864, and from the beginning our policy has always been to make only a High-Grade ARM. Since January 1, 1896, our growth has been most marked. At that ime we occupied one factory with a total floor space of 17,000 square feet and employed 44 people. To-day our plant comprises six large buildings and several storehouses, over $12 \frac{1}{2}$ acres of floor space, and we employ over 1200 people. Our RIFLES, SHOTGUNS, PISTOLS, FIREARM ACCESSORIES, are absolutely the best at popular prices. Reliable and Fully Guaranteed. We issue a most interesting 160-page catalog which will be mailed upon receipt of five cenis in stamps to cover postage.

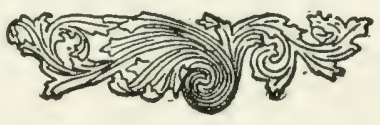

J. STEVENS ARMS \& TOOL COMPANY CHICOPEE FALLS, MASS. 







\section{PLEASE DO NOT REMOVE}

CARDS OR SLIPS FROM THIS POCKET

\section{UNIVERSITY OF TORONTO LIBRARY}

SK

33

B76

Biological

\& Medical
Browne, Bellinore H

Guns and gunning 
